University of Wollongong

Research Online

Faculty of Engineering and Information

Faculty of Engineering and Information

Sciences - Papers: Part A

Sciences

January 2016

\title{
Axial compressive behaviour of circular CFFT: Experimental database and design-oriented model
}

Qasim Khan

University of Wollongong, qsk991@uowmail.edu.au

M Neaz Sheikh

University of Wollongong, msheikh@uow.edu.au

Muhammad N. S Hadi

University of Wollongong, mhadi@uow.edu.au

Follow this and additional works at: https://ro.uow.edu.au/eispapers

Research Online is the open access institutional repository for the University of Wollongong. For further information contact the UOW Library: research-pubs@uow.edu.au 


\title{
Axial compressive behaviour of circular CFFT: Experimental database and design-oriented model
}

\author{
Abstract \\ Concrete Filled Fibre Reinforced Polymer Tube (CFFT) for new columns construction has attracted \\ significant research attention in recent years. The CFFT acts as a formwork for new columns and a barrier \\ to corrosion accelerating agents. It significantly increases both the strength capacity (Strength \\ enhancement ratio) and the ductility (Strain enhancement ratio) of reinforced concrete columns. In this \\ study, based on predefined selection criteria, experimental investigation results of 134 circular CFFT \\ columns under axial compression have been compiled and analysed from 599 CFFT specimens available \\ in the literature. It has been observed that actual confinement ratio (expressed as a function of material \\ properties of fibres, diameter of CFFT and compressive strength of concrete) has significant influence on \\ the strength and ductility of circular CFFT columns. Design oriented models have been proposed to \\ compute the strength and strain enhancement ratios of circular CFFT columns. The proposed strength \\ and strain enhancement ratio models have significantly reduced Average Absolute Error (AAE), Mean \\ Square Error (MSE), Relative Standard Error of Estimate (RSEE) and Standard Deviation (SD) as compared \\ to other available strength and strain enhancement ratios of circular CFFT column models. The \\ predictions of the proposed strength and strain enhancement ratio models match well with the \\ experimental strength and strain enhancement ratios investigation results in the compiled database.
}

\section{Keywords}

cfft, experimental, model, oriented, database, axial, design, compressive, behaviour, circular

\section{Publication Details}

Khan, Q., Sheikh, M. Neaz. \& Hadi, M. N. S. (2016). Axial compressive behaviour of circular CFFT: Experimental database and design-oriented model. Steel and Composite Structures: an international journal, 21 (4), 921-947. 


\title{
Axial compressive behaviour of circular CFFT: Experimental database and design-oriented model
}

\author{
Qasim S. Khan ${ }^{1,2 a}$, M. Neaz Sheikh ${ }^{1 \mathrm{~b}}$ and Muhammad N.S. Hadi ${ }^{* 1}$ \\ ${ }^{1}$ School of Civil, Mining and Environmental Engineering, University of Wollongong, Australia \\ ${ }^{2}$ Civil Engineering Department, University of Engineering and Technology, Lahore, Pakistan (On study leave)
}

(Received April 21, 2016, Revised June 22, 2016, Accepted June 23, 2016)

\begin{abstract}
Concrete Filled Fibre Reinforced Polymer Tube (CFFT) for new columns construction has attracted significant research attention in recent years. The CFFT acts as a formwork for new columns and a barrier to corrosion accelerating agents. It significantly increases both the strength capacity (Strength enhancement ratio) and the ductility (Strain enhancement ratio) of reinforced concrete columns. In this study, based on predefined selection criteria, experimental investigation results of 134 circular CFFT columns under axial compression have been compiled and analysed from 599 CFFT specimens available in the literature. It has been observed that actual confinement ratio (expressed as a function of material properties of fibres, diameter of CFFT and compressive strength of concrete) has significant influence on the strength and ductility of circular CFFT columns. Design oriented models have been proposed to compute the strength and strain enhancement ratios of circular CFFT columns. The proposed strength and strain enhancement ratio models have significantly reduced Average Absolute Error (AAE), Mean Square Error (MSE), Relative Standard Error of Estimate (RSEE) and Standard Deviation (SD) as compared to other available strength and strain enhancement ratios of circular CFFT column models. The predictions of the proposed strength and strain enhancement ratio models match well with the experimental strength and strain enhancement ratios investigation results in the compiled database.
\end{abstract}

Keywords: column; CFFT; confinement ratio; strength enhancement ratio; strain enhancement ratio

\section{Introduction}

In a pioneering research study, Richart et al. (1928) identified the beneficial effects of restraining the lateral dilation of concrete on the axial compressive behaviour of confined Reinforced Concrete (RC) columns. Since then a large number of studies have been conducted to investigate the effect of confinement reinforcement on the axial compressive strength and ductility of RC columns. In the last three decades, strengthening and retrofitting of RC columns using steel tubes and FRP sheets were commonly practiced. The strength and ductility of RC columns may deteriorate with time due to the development of micro-cracks in concrete columns because of the bending and shear stresses, fatigue and shrinkage. An increase in the rate of micro-cracking in

*Corresponding author, Associate Professor, E-mail: mhadi@uow.edu.au

${ }^{a}$ Ph.D. Candidate, Assistant Professor, E-mail: qsk991@uowmail.edu.au

${ }^{\mathrm{b}}$ Ph.D., Senior Lecturer, E-mail: msheikh@uow.edu.auil 
concrete may expose steel reinforcement to the air and humidity, which may increase the rate of corrosion in the steel reinforcement. Initially, steel tubes were investigated for strengthening and retrofitting of damaged RC columns and also, an alternative of steel RC columns (Zhao et al. 2002, Johansson 2003, Han et al. 2004, Sakino et al. 2004, Ishizawa et al. 2006, Lee 2007, Choi and Xiao 2010, Woo et al. 2010, Park and Choi 2013 and Aslani et al. 2015). However, steel as confinement reinforcement has few disadvantages. Steel is a corrosive material. It has high density and consequently increases dead load of the structure, which may cause additional force demand in an earthquake. Steel has significantly higher axial elastic modulus than concrete, which may result in higher axial and lateral strains in steel tubes than in the concrete core. The difference in the lateral strains between the concrete core and the steel tube may create a gap and hence may reduce the confinement effectiveness (Saafi et al. 1999). Due to the above limitations, steel tubes made ways for strengthening columns with FRP sheet, as FRP sheets have higher strength to weight ratio, increased corrosion resistance and electromagnetic neutrality, and lower axial elastic modulus than steel (Lam and Teng 2003).

In the last few decades, the behaviour of RC columns strengthened with FRP sheets has been extensively investigated. This is especially because, in the USA, UK and Canada, the performance of a large number of RC bridge and building columns have deteriorated due to the corrosion in steel reinforcement (Saafi et al. 1999). Demers and Neale (1994), Nanni and Bradford (1995), Karbhari and Gao (1997), Berthet et al. (2005), Wu et al. (2006), Youssef et al. (2007), Wu and Jiang (2013) reported an increase in the FRP sheet confined concrete strength and strain between $36 \%$ and $186 \%$, and $41 \%$ and $140 \%$, respectively. Lam and Teng (2002), Realfonzo and Napoli (2011), Ozbakkaloglu and Lim (2013), Pham and Hadi (2013, 2014a, b), Lim and Ozbakkaloglu (2014) and Sadeghian and Fam (2015) compiled a database of experimental investigations of FRP sheet confined concrete columns to develop models to determine confined concrete strength and strain of FRP sheet confined concrete columns. The increases in the strength and strain were found to depend on the material characteristics of FRP sheets (thickness, modulus of elasticity and orientation of fibres), unconfined concrete strength, diameter and height to diameter ratio of FRP sheet confined concrete columns.

Considering the beneficial effects of FRP material, Concrete Filled Fibre Reinforced Polymer Tube (CFFT) technique was proposed for new column constructions (Mirmiran and Shahawy 1996, Saafi et al. 1999, Lillistone and Jolly 2000). In CFFT columns, FRP tube acts as both longitudinal and transverse reinforcement to concrete columns. It also serves as a formwork and prevents ingress of harmful chlorides and salts, and hence slows down the deterioration in the strength and ductility of concrete columns (Lillistone and Jolly 2000). The influence of different aspects of circular CFFT columns including tube thickness, diameter of the tube, tube height to diameter ratio, unconfined concrete strength, cross sectional shape, orientation of fibres, fibre type, tube manufacturing method, specimen end condition and loading (Axial, flexural and seismic) conditions on the strength and strain enhancement ratios of CFFT columns were investigated by Lillistone and Jolly (1997, 2000), Mastrapa (1997), Jolly and Lillistone (1998a, b), Samaan et al. (1998), Matthys et al. (1999), Saafi et al. (1999), Tegola and Manni (1999), Fam and Rizkalla (2001a, b, 2002), Harries and Carey (2002), Hong and Kim (2004), Cole and Fam (2006), Ozbakkaloglu and Saatcioglu (2006), Li and Ou (2007), Mohamed and Masmoudi (2008a, b), Ozbakkaloglu and Oehlers (2008a), Park et al. (2011), Ozbakkaloglu (2013a, b), Ozbakkaloglu and Vincent (2013), Idris and Ozbakkaloglu (2013), Vincent and Ozbakkaloglu (2013a, b), Hadi et al. $(2015,2016)$.

A comprehensive and systematic review of experimental behaviour of CFFT columns is 
important to understand the behaviour of CFFT column. Although, a large number of studies investigated the properties of CFFT column but to the knowledge of the Authors there is no comprehensive review study (database) available in the literature which exclusively compiled experimental results of CFFT columns (refer to Section 2). In this paper, a systematically compiled database of circular CFFT columns tested under axial compression is presented. A total of 599 CFFT specimens tests from 30 different studies are collated after an extensive literature survey. All the CFFT columns are assessed against carefully established selection criteria (Section 3.2) for uniformity and reliability of the experimental data. The number of circular CFFT columns data points under axial compression was reduced to 134, after critical assessment. The database includes only circular CFFT columns under axial compression and does not include steel or FRP bar reinforced CFFT columns or CFFT columns under eccentric, flexural, cyclic or seismic loadings. The database may even serve as a reference for future studies on circular CFFT columns under other loadings. The compiled CFFT database is used to study the influence of different parameters on the confined concrete strength (strength enhancement ratio) and ductility (strain enhancement ratio) of CFFT columns. Also, design oriented strength and strain enhancement ratios models of circular CFFT columns are presented.

\section{Review of available FRP confined concrete column database}

A literature review of the available studies on FRP confined concrete columns showed that only Lam and Teng (2002), De Lorenzis and Tepfers (2003), Ozbakkaloglu and Lim (2013) and Lim and Ozbakkaloglu (2014) compiled experimental investigation results of 50, 41, 77 and 76 circular CFFT columns, respectively. These database studies also included a large number of FRP sheet confined concrete columns. The main focus of these studies was to investigate the behaviour of FRP sheet confined concrete columns, rather than to investigate the exclusive behaviour of circular CFFT columns.

The general stress-strain behaviours of FRP sheet confined concrete columns and Concrete Filled Fibre Reinforced Polymer Tube (CFFT) columns subjected to concentric axial compression are similar. The stress-strain diagram consists of two rising curves connected at a transition point $\left(f_{c o}, \varepsilon_{c o}\right)$ close to the unconfined concrete strength (Ozbakkaloglu et al. 2012) (Fig. 1). The slope of the first curve is the same as the slope of unconfined concrete stress strain curve, as during this stage the dilation of concrete is small and passive FRP confinement is almost inactive. The slope of the second curve is primarily dependent on the confinement stiffness of FRP. However, the ultimate confined concrete conditions (i.e., confined concrete strength and ultimate confined concrete strain) of FRP sheet confined concrete columns and CFFT columns are different. Due to higher bond stress between FRP sheet and concrete column than FRP tube and concrete column, the confined concrete strength and strain of FRP sheet confined concrete columns are higher than those of FRP tube confined concrete columns (Toutanji 1999 and Saafi et al. 1999). The higher confined concrete strength and strain could possibly be due to the fact that FRP sheets in FRP confined concrete columns are subjected to only tensile circumferential stresses, whereas FRP tubes in CFFT columns are subjected to both axial compressive and tensile circumferential stresses which may result in the reduction of bond stress between FRP tube and concrete columns. The difference between FRP sheets and FRP tubes confined concrete columns may also be due to the adhesives used to bond FRP sheets to concrete columns, whereas no such bond exists between FRP tube and concrete columns (Lam and Teng 2002). Moreover, FRP tube confinement has 


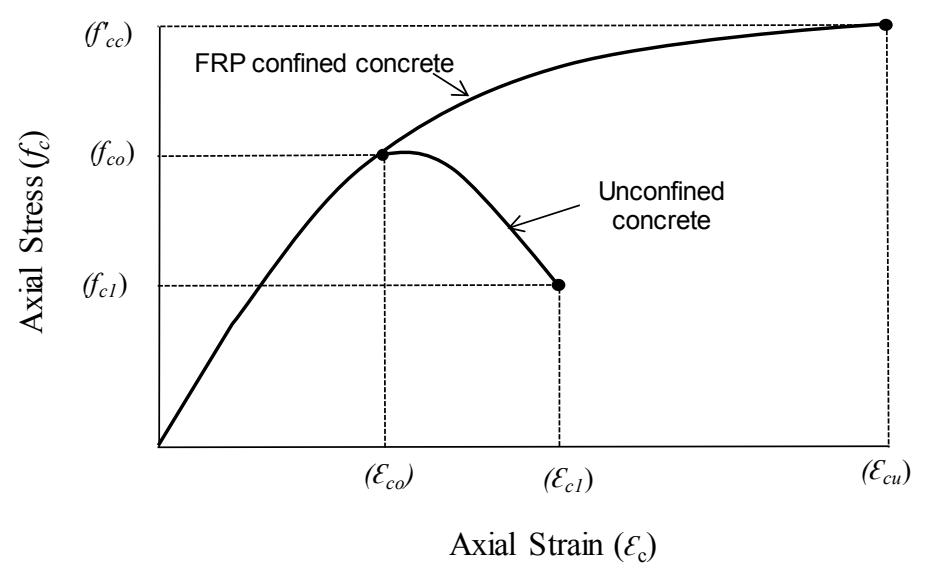

Fig. 1 Axial stress-axial strain behaviour of unconfined and FRP confined concrete columns

higher axial stiffness than FRP sheet confinement resulting in different circumferential strains and failure patterns of confined concrete columns (Lam and Teng 2003). Ozbakkaloglu and Lim (2013) also recognised lower confined concrete strengths of FRP tube confined concrete columns than those of FRP sheet confined concrete columns. In general, strength enhancement ratio $\left(f_{c c}^{\prime} / f_{c o}\right)$ is defined as a ratio of FRP confined concrete strength $\left(f_{c c}^{\prime}\right)$ to unconfined concrete strength $\left(f_{c o}\right)$ while strain enhancement ratio $\left(\varepsilon_{c u} / \varepsilon_{c o}\right)$ is a ratio of FRP confined concrete strain corresponding to $\left(\varepsilon_{c u}\right)$ to unconfined concrete strain corresponding to $f_{c o}\left(\varepsilon_{c o}\right)$ as shown in Fig. 1.

Lam and Teng (2002) proposed a linear model to determine the strength enhancement ratio $\left(f_{c c}^{\prime}\right.$ $\left./ f_{c o}\right)$ as a function of nominal confinement ratio $\left(f_{l} / f_{c o}\right)$ for circular FRP sheet confined columns with unconfined concrete strength less than $65 \mathrm{MPa}$ (Eq. (1)). The model was recommended to compute the confined concrete strength of circular FRP tube confined concrete columns having nominal confinement ratios less than 1.0.

$$
\frac{f_{c c}^{\prime}}{f_{c o}}=1+2\left(\frac{f_{l}}{f_{c o}}\right)
$$

The nominal confinement ratio $\left(f_{l} / f_{c o}\right)$ (Eq. 2) is defined as the ratio of nominal confinement pressure $\left(f_{l}\right)$ to unconfined concrete strength $\left(f_{c o}\right)$. The $f_{l}$ is expressed in terms of FRP tube thickness $\left(t_{f}\right)$, diameter of CFFT $(D)$, modulus of elasticity of fibres $\left(E_{f}\right)$ and ultimate tensile strain of fibres $\left(\varepsilon_{f u}\right)$.

$$
\frac{f_{l}}{f_{c o}}=\frac{2 E_{f} t_{f} \varepsilon_{f u}}{D f_{c o}}
$$

De Lorenzis and Tepfers (2003) proposed a non-linear model for the strain enhancement ratio $\left(\varepsilon_{c u} / \varepsilon_{c o}\right)$ as functions of actual confinement ratio $\left(f_{l, a} / f_{c o}\right)$ and confinement modulus $\left(K_{l}\right)$ (Eqs. 3-5). The actual confinement ratio $\left(f_{l, a} / f_{c o}\right)$ is defined as the ratio of actual confinement pressure $\left(f_{l, a}\right)$ to unconfined concrete strength $\left(f_{c o}\right)$. The $f_{l, a}$ is expressed in terms of FRP tube thickness $\left(t_{f}\right)$, diameter of CFFT $(D)$, modulus of elasticity of fibres $\left(E_{f}\right)$ and experimentally obtained circumferential rupture strain of fibres $\left(\varepsilon_{\text {rup }}\right)$. 


$$
\begin{gathered}
\frac{\varepsilon_{c u}}{\varepsilon_{c o}}=1+26.2\left(\frac{f_{l, a}}{f_{c o}}\right)^{0.68} K_{l}^{-0.127} \\
\frac{f_{l, a}}{f_{c o}}=\frac{2 E_{f} t_{f} \varepsilon_{r u p}}{D f_{c o}} \\
K_{l}=\frac{2 E_{f} t_{f}}{D}
\end{gathered}
$$

Ozbakkaloglu and Lim (2013) and Lim and Ozbakkaloglu (2014) presented strength enhancement ratio $\left(f_{c c}^{\prime} / f_{c o}\right)$ as a function of net confining pressure, that is, the reduced actual confinement pressure $\left(f_{l, a}\right)$ after subtraction of the threshold confinement pressure $\left(f_{l, o}\right)$ for FRP confined concrete columns (Eqs. 6-10).

$$
\frac{f_{c c}^{\prime}}{f_{c o}}=c_{1}+3.2 \frac{\left(f_{l, a}-f_{l, o}\right)}{f_{c o}}
$$

where

$$
\begin{gathered}
c_{1}=1+0.0058 \frac{K_{l}}{f_{c o}} \\
f_{l, o}=K_{l} \varepsilon_{l 1} \\
\varepsilon_{l 1}=\left(0.43+0.009 \frac{K_{l}}{f_{c o}}\right) \varepsilon_{c o} \\
K_{l}=\frac{2 E_{f} t_{f}}{D} \text { and } K_{l} \geq f_{c o}^{1.65}
\end{gathered}
$$

Ozbakkaloglu and Lim (2013) and Lim and Ozbakkaloglu (2014) presented strain enhancement ratio $\left(\varepsilon_{c u} / \varepsilon_{c o}\right)$ as a nonlinear function of $K_{l}, \varepsilon_{r u p}$ and $f_{c o}$ for FRP confined concrete columns (Eqs. (11)-(12)).

$$
\frac{\varepsilon_{c u}}{\varepsilon_{c o}}=c_{2} \varepsilon_{c o}+0.27\left(\frac{K_{l}}{f_{c o}}\right) \varepsilon_{r u p}^{1.35}
$$

where

$$
c_{2}=2-\left(\frac{f_{c o}-20}{100}\right) \text { and } c_{2} \geq 1
$$

These models are applicable to circular FRP confined concrete columns only when fibres are orientated along the circumferential direction and height to diameter ratio $(H / D)$ equal to or less than 3.0. 


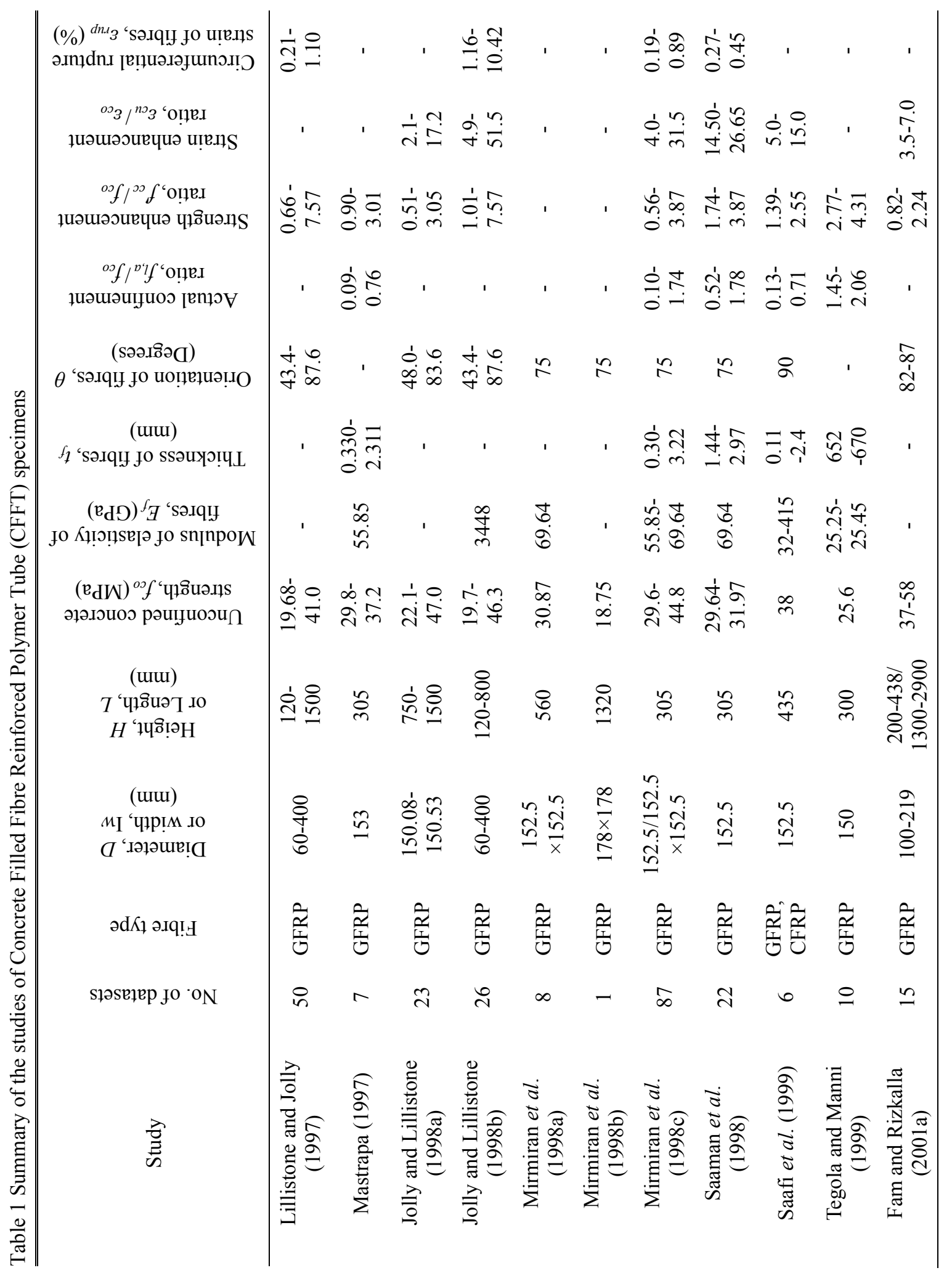




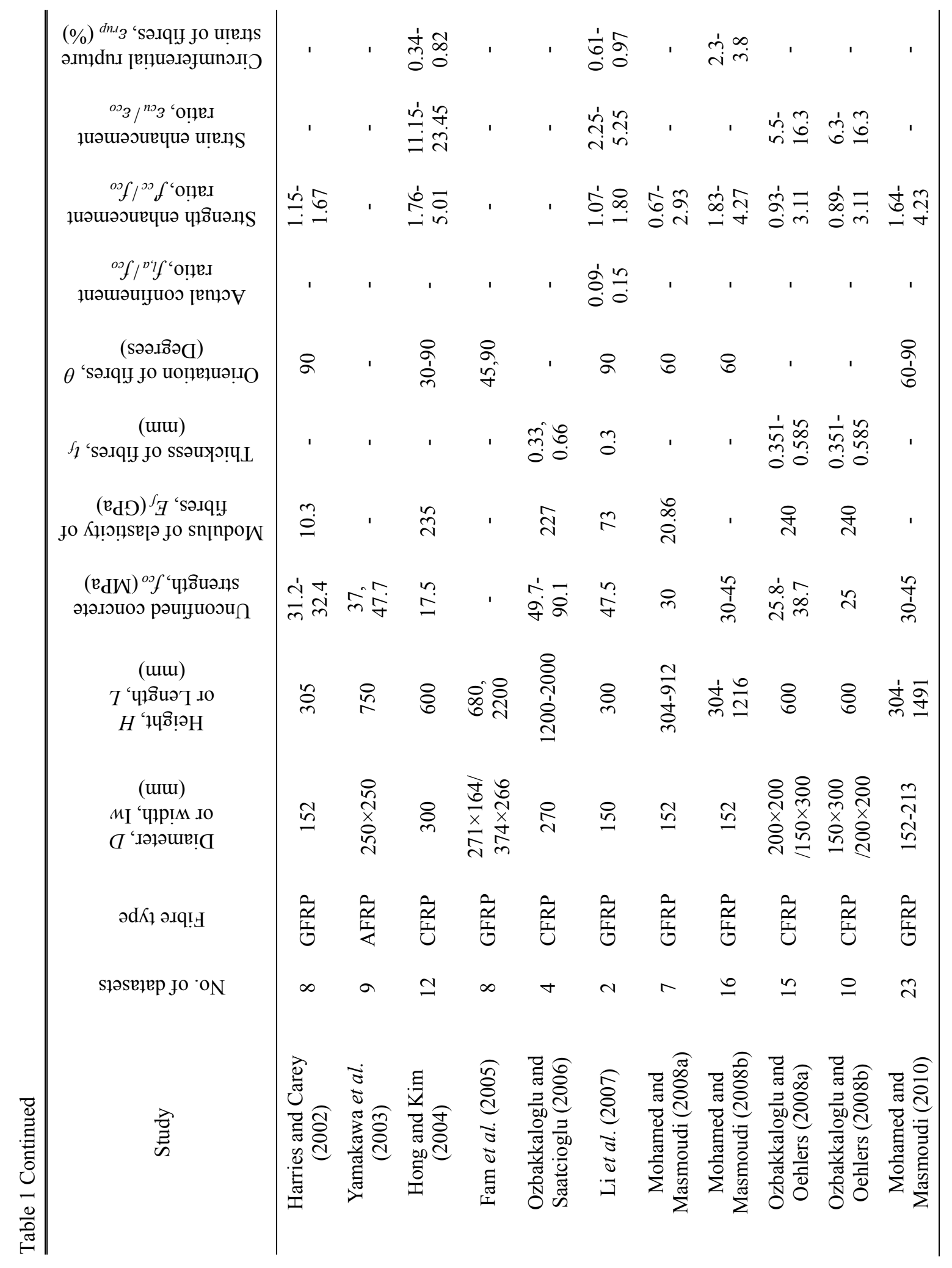




\begin{tabular}{|c|c|c|c|c|c|c|c|c|}
\hline 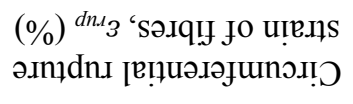 & & ' & $\begin{array}{l}+ \\
\infty \\
0\end{array}$ & $m_{0}^{1} \tilde{n}$ & $\begin{array}{l}\dot{1} \tilde{C} \\
\stackrel{0}{0}\end{array}$ & 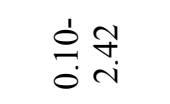 & 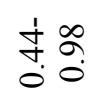 & $\stackrel{n}{n} \stackrel{\sim}{+}$ \\
\hline 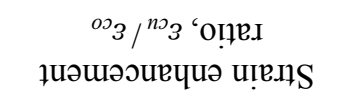 & & ' & ' & ' & $\stackrel{1}{\stackrel{\infty}{\varrho}}$ & $\begin{array}{l}0 \\
2 \\
-1 \\
-1\end{array}$ & $\stackrel{1}{6} \stackrel{8}{0}$ & 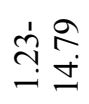 \\
\hline 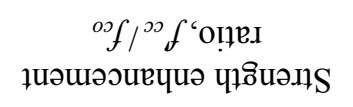 & $\underset{\dot{0}}{\dot{0}} \stackrel{\overrightarrow{\mathrm{i}}}{\mathrm{i}}$ & 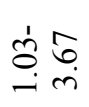 & $\stackrel{1}{+}$ & $\stackrel{+}{\stackrel{t}{0}}$ & $\begin{array}{l}\dot{b}= \\
\stackrel{0}{0}=\end{array}$ & 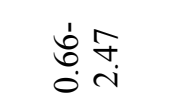 & 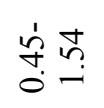 & 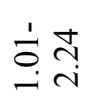 \\
\hline 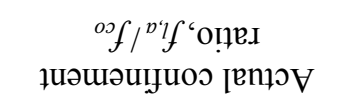 & & ' & 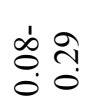 & ' & $\begin{array}{ll}1 & 0 \\
0 & 0 \\
0 & 0\end{array}$ & 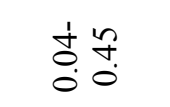 & 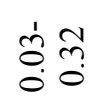 & $\stackrel{1}{1} \stackrel{\infty}{0}$ \\
\hline 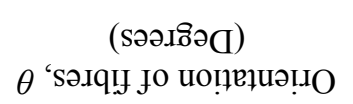 & 8 & 8 & \& & \& & \& & \& & \& & 字 \\
\hline 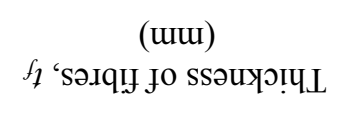 & & ' & $\stackrel{5}{=}$ & $\begin{array}{l}\text { \&் } \\
\stackrel{0}{0}=\end{array}$ & $\begin{array}{l}\dot{1} \\
\stackrel{1}{\Xi} \\
0\end{array}$ & 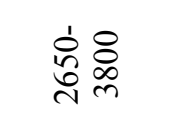 & 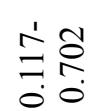 & : \\
\hline 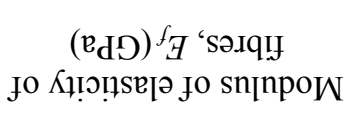 & & ' & $\stackrel{0}{\exists} \underset{\sim}{\sim}$ & 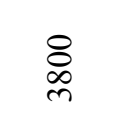 & $\begin{array}{l}\text { ợ } \\
\text { à } \\
\text { à }\end{array}$ & $\begin{array}{l}\text { Oơ } \\
\text { b } \\
ٍ=\end{array}$ & $\stackrel{\stackrel{+}{N}}{ }$ & ลे \\
\hline 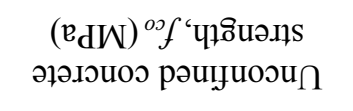 & in & 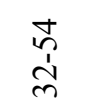 & ชุ & $\stackrel{9}{\stackrel{2}{2}}$ & 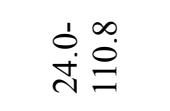 & $\stackrel{\dot{m}}{\dot{m}}$ & $\begin{array}{l}\dot{b} \tilde{n} \\
\dot{m} \widehat{c}\end{array}$ & $\begin{array}{l}\dot{+}+\infty \\
\dot{\sigma} \infty\end{array}$ \\
\hline 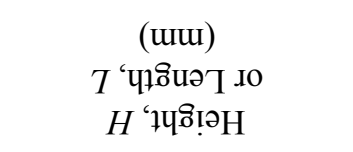 & di & $\begin{array}{l}8 \\
8 \\
0 \\
8 \\
0\end{array}$ & 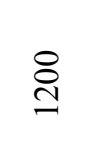 & \&্ల & 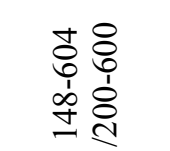 & $\begin{array}{l}8 \\
0 \\
0 \\
1 \\
1\end{array}$ & $\tilde{n}$ & 离 \\
\hline 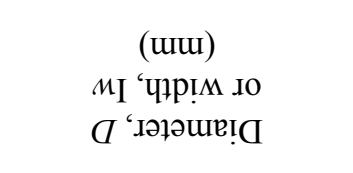 & $\tilde{\Omega}$ & in & 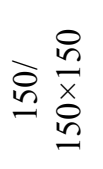 & 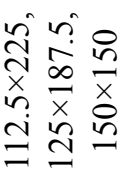 & 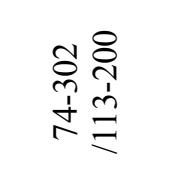 & $\begin{array}{l}8 \\
\substack{n \\
n} \\
\end{array}$ & $\approx$ & $\frac{\pi}{2}$ \\
\hline әdК ә.૧! & 产 & $\frac{a}{\frac{2}{c}}$ & 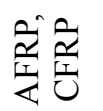 & 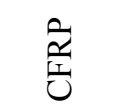 & 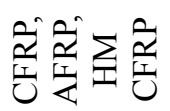 & 全运主全 & 金 & $\frac{2}{2}$ \\
\hline słəsełep јо 'oN & 으 & $=$ & 6 & $\stackrel{\sim}{\sim}$ & $q$ & $\infty$ & 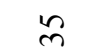 & $\infty$ \\
\hline 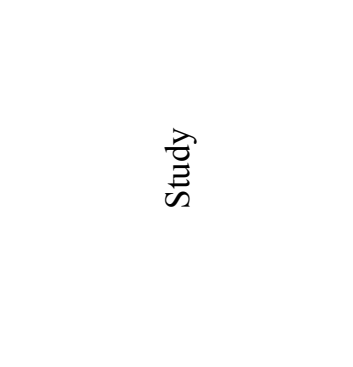 & 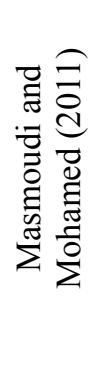 & 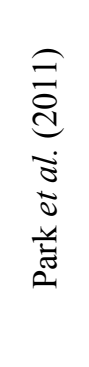 & 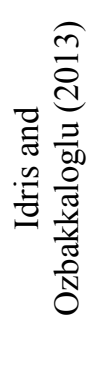 & 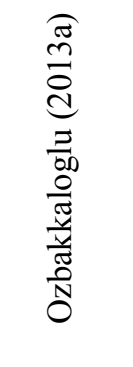 & 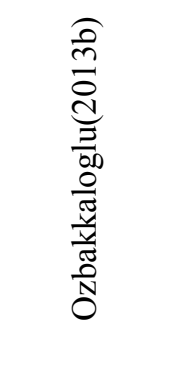 & 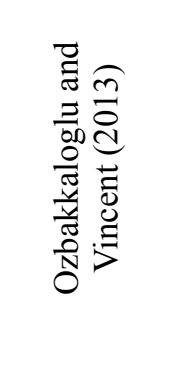 & 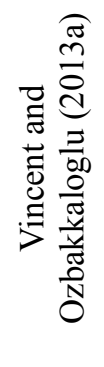 & 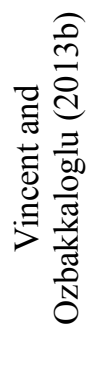 \\
\hline
\end{tabular}


The above literature review indicates the need of confined concrete strength and strain models specifically developed for circular CFFT columns that are validated with a large number of circular CFFT columns. The available design oriented strength and strain enhancement ratio models were developed using experimental investigation results of FRP confined (FRP sheet and FRP tube) concrete columns under axial compression available at the time of the compilation of the databases. The available databases consisted of smaller number of circular CFFT columns. It is noted that the main purpose of the available design oriented models was to predict the strength and strain enhancement of FRP confined concrete columns, not specifically the strength and strain enhancement of circular CFFT columns. Extensive review of literature revealed that a large number of experimental investigation results of CFFT columns summarized in Table 1 were not included in the existing databases. Hence, there is a need to compile a database of circular CFFT columns under axial compression and develop accurate design oriented strength and strain enhancement ratio models solely for circular CFFT columns. The objective of this study is to compile the available experimental results of CFFT columns (Database) and develop strength and strain enhancement ratio models.

\section{Experimental database of circular CFFT Columns}

\subsection{Description of the compiled studies}

A total of 599 CFFT data points from 30 different experimental studies have been collated after a comprehensive literature survey. The key information of the compiled studies such as Authors of study, number of datasets, fibre type, diameter $(D)$ or width $(w)$, height $(H)$ or length $(L)$, unconfined concrete strength $\left(f_{c o}\right)$, modulus of elasticity of fibres $\left(E_{f}\right)$, thickness of fibres $\left(t_{f}\right)$, orientation of fibres $(\theta)$, actual confinement ratio $\left(f_{l, a} / f_{c o}\right)$, strength enhancement ratio $\left(f_{c c}^{\prime} / f_{c o}\right)$, strain enhancement ratio $\left(\varepsilon_{c u} / \varepsilon_{c o}\right)$, and circumferential rupture strain $\left(\varepsilon_{r u p}\right)$ is presented in Table 1. After systematically assessing the CFFT data points presented in Table 1, based on predefined selection criteria in Section 3.2, 134 circular CFFT column data points (database) have been shortlisted.

\subsection{Selection criteria of the CFFT database}

The aim of this paper is to develop design oriented model to predict the confined concrete strength and ultimate confined concrete strain of circular CFFT under axial compression. The selection criteria were adopted to ensure the reliability and suitability of the compiled database to accurately predict the confined concrete strength and ultimate confined concrete strain of circular CFFT columns under axial compression. The compiled database is the most comprehensive database of circular CFFT columns reported in the literature. The CFFT database presented in this study includes only circular CFFT columns subjected to concentric axial compression. Square, rectangular and hollow CFFT columns, columns reinforced with either steel or FRP longitudinal bars, and columns subjected to eccentric, cyclic, flexural or seismic loading have been excluded from the database. In case of non-circular (square and rectangle) cross sections, confinement pressure $\left(f_{l}\right)$ is non-uniform and higher at corners than in other parts of the tube. Confinement pressure, however, is uniformly distributed in circular cross sections. Hollow and partially filled CFFT columns have reduced confinement pressures than solid and completely filled CFFT columns for same geometric, fibre and FRP properties, resulting in significant reduction in the 
strength and strain enhancement ratios of hollow CFFT columns. A void in the hollow or partially filled tubes decreases the internal support provided by the concrete core to FRP tube. Hence, the void reduces the confinement effectiveness of tubes and affects the final failure mode of CFFT columns. Steel or FRP reinforced CFFT columns have higher strength and strain enhancement ratios than unreinforced CFFT columns. Although the final failure mode is similar (circumferential rupture of fibres), the overall behaviour of steel or FRP reinforced CFFT columns is different from unreinforced CFFT columns. CFFT columns subjected to eccentric loading have also been excluded from the database as eccentric loading will result in the reduced strength and strain enhancement ratios. The CFFT columns subjected to flexural, cyclic and seismic loading have significantly different failure mode than CFFT columns subjected to concentric axial compression. The selection criteria adopted in this study are presented below:

Specimens confined with FRP sheets or bonded FRP sheets have been excluded from the database. Only circular specimens confined with FRP tubes have been included. Hence, the columns in Mirmiran et al. (1998b), Harries and Carey (2002), Yamakawa et al. (2003), Fam et al. (2005), Ozbakkaloglu and Oehlers (2008a, b) and Ozbakkaloglu (2013a) have not been considered.

The specimens having either transverse or longitudinal reinforcement have been excluded from the database. Hence, the CFFT columns in Jolly and Lillistone (1998a), Mohamed and Masmoudi (2008b, 2010), Masmoudi and Mohamed (2011), and Park et al. (2011) have not been included.

Only circular FRP tube confined concrete columns subjected to concentric loading are included. Circular CFFT columns subjected to flexural, eccentric or seismic loading have been excluded from the database. Hence, the columns in Mirmiran et al. (1998c), Fam and Rizkalla (2001a), Fam et al. (2005), Ozbakkaloglu and Saatcioglu (2006), Idris and Ozbakkaloglu (2013), and Ozbakkaloglu (2013a) have been omitted.

The specimens in which failure mode is due to rupture of CFFT are included and all those specimens in which premature failure due to debonding or large eccentricities occurred have been discarded. Hence, columns in Jolly and Lillistone (1998a), and Mohamed and Masmoudi (2008a) have been ignored.

The specimens with fibres orientated other than circumferential direction have been excluded from the database. Hence the column specimens in Mirmiran et al. (1998a) and Samaan et al. (1998) have not been considered.

The specimens whose geometric parameters, unconfined and confined concrete conditions were either not completely mentioned or cannot be calculated have been excluded from the database. Hence, columns in Lillistone and Jolly (1997), Mastrapa (1997), Jolly and Lillistone (1998b), Tegola and Manni (1999) and Hong and Kim (2004) have been disregarded.

\subsection{Description of the CFFT database}

The detailed information of the selected circular CFFT columns including column geometrical properties (diameter, $D$; and height to diameter ratio, $H / D$ ), concrete properties (unconfined concrete strength, $f_{c o}$; and unconfined concrete strain, $\varepsilon_{c o}$ ), fibre properties (modulus of elasticity of fibres, $E_{f}$; ultimate tensile strength of fibres, $f_{f i}$; ultimate tensile strain of fibres, $\varepsilon_{f u}$; and thickness of fibres, $t_{f}$ ), FRP properties (circumferential rupture strain, $\varepsilon_{r u p}$; actual confinement ratio, $f_{l, a} / f_{c o}$; and strain reduction factor, $k_{\varepsilon}$ ), and strength and ductility (strength enhancement ratio, $f_{c c}^{\prime} / f_{c o}$; and strain enhancement ratio, $\varepsilon_{c u} / \varepsilon_{c o}$ ) is presented in Table 2 . The CFFT columns database in Table 2 includes 64 Carbon FRP (CFRP), 55 Aramid FRP (AFRP), 10 High Modulus Carbon FRP (HMCFRP) and 5 Glass FRP (GFRP) tube reinforced concrete columns. 
Table 2 Details of circular CFFT columns included in this study

\begin{tabular}{|c|c|c|c|c|c|c|c|c|c|c|c|c|c|}
\hline \multirow{2}{*}{ 突 } & \multicolumn{2}{|c|}{$\begin{array}{l}\text { Column } \\
\text { geometric } \\
\text { properties }\end{array}$} & \multicolumn{2}{|c|}{$\begin{array}{l}\text { Concrete } \\
\text { properties }\end{array}$} & \multicolumn{4}{|c|}{ Fibre properties } & \multicolumn{3}{|c|}{ FRP properties } & \multicolumn{2}{|c|}{$\begin{array}{c}\text { Strength and } \\
\text { ductility } \\
\text { capacity }\end{array}$} \\
\hline & $\begin{array}{c}D \\
(\mathrm{~mm})\end{array}$ & $H / D$ & $\begin{array}{c}f_{c o} \\
(\mathrm{MPa})\end{array}$ & $\begin{array}{c}\varepsilon_{c o} \\
(\%)\end{array}$ & $\begin{array}{c}E_{f} \\
(\mathrm{GPa})\end{array}$ & $\begin{array}{c}f_{f u} \\
(\mathrm{MPa})\end{array}$ & $\begin{array}{c}\varepsilon_{f u} \\
(\%)\end{array}$ & $\begin{array}{c}t_{f} \\
(\mathrm{~mm})\end{array}$ & $\begin{array}{l}\varepsilon_{\text {rup }} \\
(\%)\end{array}$ & $\frac{f_{l, a}}{f_{c o}}$ & $k_{\varepsilon}$ & $\frac{f_{c c}^{\prime}}{f_{c o}}$ & $\frac{\varepsilon_{c u}}{\varepsilon_{c o}}$ \\
\hline \multirow{6}{*}{ 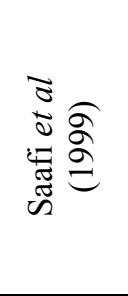 } & 152.5 & 2.9 & 38.0 & 0.20 & 32 & 450 & 1 . & 0.80 & 1.41 & 0.13 & 0.85 & 1.39 & 9.50 \\
\hline & 152.5 & 2.9 & 38.0 & 0.20 & 34 & 505 & 1.7 & 1.60 & 1.49 & 0.28 & 0.89 & 1.74 & 12.40 \\
\hline & 152.5 & 2.9 & 38.0 & 0.20 & 36 & 560 & 1.7 & 2.40 & 1.56 & 0.48 & 0.94 & 2.18 & 15.00 \\
\hline & 152.5 & 2.9 & 38.0 & 0.20 & 367 & 3300 & 1.7 & 0.11 & 0.90 & 0.13 & 0.54 & 1.45 & 5.00 \\
\hline & 152.5 & 2.9 & 38.0 & 0.20 & 390 & 3550 & 1.7 & 0.23 & 0.91 & 0.28 & 0.55 & 1.79 & 8.00 \\
\hline & 152.5 & 2.9 & 38.0 & 0.20 & 415 & 3700 & 1.7 & 0.55 & 0.89 & 0.71 & 0.53 & 2.55 & 11.10 \\
\hline \multirow{2}{*}{$\begin{array}{l}\text { Li et al. } \\
(2007)\end{array}$} & 150 & 2.0 & 47.5 & 040 & 73 & 1800 & 2 & 030 & 1.50 & 009 & 061 & 1.07 & 2.25 \\
\hline & 150 & 2.0 & 47.5 & 0.40 & 73 & 1800 & 2.5 & 0.30 & 2.40 & 0.15 & 0.97 & 1.80 & 5.25 \\
\hline \multirow{26}{*}{ 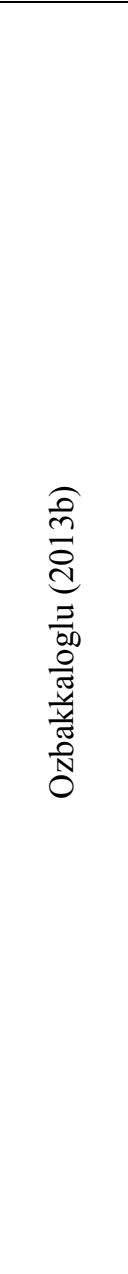 } & 74 & 2.0 & 43.0 & 0.87 & 240 & 3800 & 1.6 & 0.12 & 1.20 & 0.21 & 0.77 & 1.61 & 5.80 \\
\hline & 152 & 2.0 & 36.4 & 0.88 & 240 & 3800 & 1.6 & 0.23 & 1.30 & 0.26 & 0.84 & 1.67 & 6.40 \\
\hline & 302 & 2.0 & 36.3 & 0.97 & 240 & 3800 & 1.6 & 0.47 & 1.17 & 0.24 & 0.75 & 1.57 & 6.60 \\
\hline & 100 & 2.0 & 83.6 & 1.20 & 116 & 2900 & 2.5 & 0.20 & 1.84 & 0.10 & 0.74 & 1.36 & 5.70 \\
\hline & 152 & 2.0 & 77.9 & 1.33 & 116 & 2900 & 2.5 & 0.30 & 1.83 & 0.11 & 0.73 & 1.39 & 6.60 \\
\hline & 100 & 2.0 & 110.1 & 1.38 & 116 & 2900 & 2.5 & 0.40 & 1.52 & 0.13 & 0.61 & 1.70 & 7.70 \\
\hline & 152 & 2.0 & 104.5 & 1.28 & 116 & 2900 & 2. & 0.60 & 1.58 & 0.14 & 0.63 & 1.66 & 7.10 \\
\hline & 100 & 2.0 & 35.5 & 0.23 & 116 & 2900 & 2. & 0.20 & 2.18 & 8 & 37 & 1.87 & 8.30 \\
\hline & 100 & 2.0 & 83.6 & 0.29 & 116 & 2900 & 2. & 0.40 & 1.84 & 0.20 & 4 & 1.36 & 5.70 \\
\hline & 100 & 2.0 & 110.1 & 0.30 & 116 & 2900 & 2.5 & 0.60 & 1.55 & 0.20 & 0.62 & 1.40 & 6.20 \\
\hline & 100 & 2.0 & 85.9 & 0.29 & 116 & 2900 & 2.5 & 0.60 & 1.85 & 0.30 & 0.74 & 1.79 & 7.60 \\
\hline & 100 & 2.0 & 110.1 & 0.30 & 116 & 2900 & 2.5 & 0.80 & 1.52 & 0.26 & 0.61 & 1.70 & 7.70 \\
\hline & 100 & 2.0 & 36.6 & 0.23 & 99 & 2930 & 3.0 & 0.60 & 2.24 & 0.73 & 0.77 & 2.44 & 13.70 \\
\hline & 100 & 2.0 & 84.9 & 0.29 & 99 & 2930 & 3.0 & 0.60 & 2.18 & 0.31 & 0.75 & 1.99 & 9.70 \\
\hline & 100 & 2.0 & 110.1 & 0.30 & 99 & 2930 & 3.0 & 0.60 & 2.13 & 0.23 & 0.73 & 2.12 & 10.40 \\
\hline & 152 & 2.0 & 36.4 & 0.23 & 240 & 3800 & 1.6 & 0.23 & 1.30 & 0.26 & 0.84 & 1.67 & 6.40 \\
\hline & 152 & 2.0 & 59.0 & 0.26 & 240 & 3800 & 1.6 & 0.47 & 0.97 & 0.24 & 0.62 & 1.41 & 4.90 \\
\hline & 152 & 2.0 & 102.5 & 0.30 & 240 & 3800 & 1.6 & 0.70 & 0.89 & 0.19 & 0.57 & 1.28 & 4.30 \\
\hline & 152 & 2.0 & 102.2 & 0.33 & 116 & 2900 & 2.5 & 0.80 & 1.18 & 0.14 & 0.47 & 1.20 & 4.40 \\
\hline & 152 & 2.0 & 102.5 & 0.34 & 240 & 3800 & 1.6 & 0.59 & 0.81 & 0.15 & 0.52 & 1.13 & 3.10 \\
\hline & 152 & 2.0 & 59.0 & 0.26 & 240 & 3800 & 1.6 & 0.23 & 1.17 & 0.15 & 0.75 & 1.13 & 3.90 \\
\hline & 152 & 2.0 & 59.0 & 0.26 & 640 & 2650 & 0.4 & 0.38 & 0.12 & 0.07 & 0.29 & 1.25 & 1.70 \\
\hline & 100 & 2.0 & 85.9 & 0.29 & 116 & 2900 & 2.5 & 0.60 & 1.85 & 0.30 & 0.74 & 1.79 & 7.60 \\
\hline & 100 & 2.0 & 84.9 & 0.29 & 99 & 2930 & 3.0 & 0.60 & 2.18 & 0.31 & 0.75 & 1.99 & 9.70 \\
\hline & 152 & 2.0 & 49.4 & 0.25 & 116 & 2900 & 2.5 & 0.60 & 2.32 & 0.43 & 0.93 & 2.15 & 13.70 \\
\hline & 152 & 2.0 & 49.4 & 0.25 & 116 & 2900 & 2.5 & 0.60 & 2.24 & 0.42 & 0.90 & 2.14 & 14.10 \\
\hline
\end{tabular}


Table 2 Continued

\begin{tabular}{|c|c|c|c|c|c|c|c|c|c|c|c|c|c|}
\hline \multirow{2}{*}{ 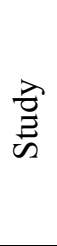 } & \multicolumn{2}{|c|}{$\begin{array}{l}\text { Column } \\
\text { geometric } \\
\text { properties }\end{array}$} & \multicolumn{2}{|c|}{$\begin{array}{l}\text { Concrete } \\
\text { properties }\end{array}$} & \multicolumn{4}{|c|}{ Fibre properties } & \multicolumn{3}{|c|}{ FRP properties } & \multicolumn{2}{|c|}{$\begin{array}{c}\text { Strength and } \\
\text { ductility } \\
\text { capacity }\end{array}$} \\
\hline & $\begin{array}{c}D \\
(\mathrm{~mm})\end{array}$ & $H / D$ & $\begin{array}{c}f_{c o} \\
(\mathrm{MPa})\end{array}$ & $\begin{array}{c}\varepsilon_{c o} \\
(\%)\end{array}$ & $\begin{array}{c}E_{f} \\
(\mathrm{GPa})\end{array}$ & $\begin{array}{c}f_{f u} \\
(\mathrm{MPa})\end{array}$ & $\begin{array}{c}\varepsilon_{f u} \\
(\%)\end{array}$ & $\begin{array}{c}t_{f} \\
(\mathrm{~mm})\end{array}$ & $\begin{array}{l}\varepsilon_{\text {rup }} \\
(\%)\end{array}$ & $\frac{f_{l, a}}{f_{c o}}$ & $k_{\varepsilon}$ & $\frac{f_{c c}^{\prime}}{f_{c o}}$ & $\frac{\varepsilon_{c u}}{\varepsilon_{c o}}$ \\
\hline \multirow{35}{*}{ 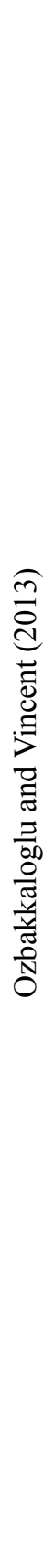 } & 75 & 2.0 & 43.0 & 0.22 & 240 & 3800 & 1.6 & 0.12 & 1.07 & 0.19 & 0.68 & 1.57 & 6.14 \\
\hline & 75 & 2.0 & 43.0 & 0.22 & 240 & 3800 & 1.6 & 0.12 & 1.32 & 0.23 & 0.83 & 1.65 & 6.55 \\
\hline & 75 & 2.0 & 43.0 & 0.22 & 240 & 3800 & 1.6 & 0.12 & 0.91 & 0.16 & 0.57 & 1.42 & 4.18 \\
\hline & 75 & 2.0 & 47.8 & 0.23 & 240 & 3800 & 1.6 & 0.12 & 0.83 & 0.13 & 0.52 & 1.27 & 3.65 \\
\hline & 100 & 2.0 & 37.0 & 0.21 & 116 & 2900 & 2.5 & 0.20 & 2.22 & 0.28 & 0.89 & 1.91 & 9.81 \\
\hline & 100 & 2.0 & 35.5 & 0.20 & 116 & 2900 & 2.5 & 0.20 & 2.08 & 0.27 & 0.83 & 1.85 & 8.75 \\
\hline & 100 & 2.0 & 34.0 & 0.20 & 116 & 2900 & 2.5 & 0.20 & 2.25 & 0.31 & 0.90 & 1.85 & 9.40 \\
\hline & 100 & 2.0 & 37.2 & 0.21 & 116 & 2900 & 2.5 & 0.30 & 2.11 & 0.39 & 0.84 & 2.40 & 14.76 \\
\hline & 100 & 2.0 & 37.2 & 0.21 & 116 & 2900 & 2.5 & 0.30 & 2.39 & 0.45 & 0.96 & 2.47 & 15.76 \\
\hline & 100 & 2.0 & 35.4 & 0.20 & 116 & 2900 & 2.5 & 0.30 & 2.21 & 0.43 & 0.88 & 2.45 & 15.20 \\
\hline & 150 & 2.0 & 37.3 & 0.21 & 240 & 3800 & 1.6 & 0.12 & 1.20 & 0.12 & 0.76 & 1.13 & 3.76 \\
\hline & 150 & 2.0 & 34.6 & 0.20 & 240 & 3800 & 1.6 & 0.12 & 0.77 & 0.08 & 0.49 & 1.20 & 3.30 \\
\hline & 150 & 2.0 & 35.5 & 0.20 & 240 & 3800 & 1.6 & 0.23 & 1.32 & 0.28 & 0.83 & 1.66 & 7.15 \\
\hline & 150 & 2.0 & 36.3 & 0.21 & 240 & 3800 & 1.6 & 0.23 & 1.36 & 0.28 & 0.86 & 1.68 & 7.29 \\
\hline & 150 & 2.0 & 37.3 & 0.21 & 240 & 3800 & 1.6 & 0.23 & 1.23 & 0.25 & 0.78 & 1.65 & 6.90 \\
\hline & 150 & 2.0 & 36.3 & 0.21 & 640 & 2650 & 0.4 & 0.19 & 0.12 & 0.05 & 0.29 & 1.28 & 1.33 \\
\hline & 150 & 2.0 & 36.3 & 0.21 & 640 & 2650 & 0.4 & 0.19 & 0.11 & 0.05 & 0.27 & 1.27 & 1.43 \\
\hline & 150 & 2.0 & 36.3 & 0.21 & 640 & 2650 & 0.4 & 0.19 & 0.18 & 0.08 & 0.43 & 1.19 & 1.19 \\
\hline & 300 & 2.0 & 36.3 & 0.21 & 240 & 3800 & 1.6 & 0.23 & 1.08 & 0.11 & 0.68 & 1.06 & 3.81 \\
\hline & 300 & 2.0 & 36.3 & 0.21 & 240 & 3800 & 1.6 & 0.47 & 1.17 & 0.24 & 0.74 & 1.57 & 7.24 \\
\hline & 75 & 2.0 & 62.0 & 0.26 & 240 & 3800 & 1.6 & 0.12 & 0.50 & 0.06 & 0.32 & 1.13 & 2.42 \\
\hline & 75 & 2.0 & 66.6 & 0.27 & 240 & 3800 & 1.6 & 0.12 & 0.36 & 0.04 & 0.23 & 1.05 & 2.11 \\
\hline & 75 & 2.0 & 55.0 & 0.25 & 240 & 3800 & 1.6 & 0.12 & 0.72 & 0.10 & 0.45 & 1.03 & 3.20 \\
\hline & 75 & 2.0 & 55.0 & 0.25 & 240 & 3800 & 1.6 & 0.23 & 1.13 & 0.31 & 0.71 & 1.75 & 5.72 \\
\hline & 75 & 2.0 & 50.3 & 0.24 & 240 & 3800 & 1.6 & 0.23 & 0.95 & 0.28 & 0.60 & 1.95 & 7.13 \\
\hline & 75 & 2.0 & 52.0 & 0.24 & 240 & 3800 & 1.6 & 0.23 & 1.07 & 0.31 & 0.68 & 2.03 & 10.04 \\
\hline & 100 & 2.0 & 85.9 & 0.31 & 116 & 2900 & 2.5 & 0.40 & 1.76 & 0.19 & 0.70 & 1.41 & 5.32 \\
\hline & 100 & 2.0 & 82.4 & 0.31 & 116 & 2900 & 2.5 & 0.40 & 1.84 & 0.21 & 0.74 & 1.30 & 5.10 \\
\hline & 100 & 2.0 & 82.4 & 0.31 & 116 & 2900 & 2.5 & 0.40 & 1.92 & 0.22 & 0.77 & 1.36 & 5.32 \\
\hline & 100 & 2.0 & 85.9 & 0.31 & 116 & 2900 & 2.5 & 0.60 & 1.62 & 0.26 & 0.65 & 1.73 & 6.19 \\
\hline & 100 & 2.0 & 85.9 & 0.31 & 116 & 2900 & 2.5 & 0.60 & 1.76 & 0.29 & 0.70 & 1.80 & 7.19 \\
\hline & 100 & 2.0 & 85.9 & 0.31 & 116 & 2900 & 2.5 & 0.60 & 2.17 & 0.35 & 0.87 & 1.86 & 7.68 \\
\hline & 100 & 2.0 & 85.9 & 0.31 & 116 & 2900 & 2.5 & 0.60 & 2.36 & 0.38 & 0.94 & 2.05 & 9.32 \\
\hline & 100 & 2.0 & 83.0 & 0.31 & 116 & 2900 & 2.5 & 0.60 & 1.74 & 0.29 & 0.70 & 1.87 & 8.16 \\
\hline & 100 & 2.0 & 85.9 & 0.31 & 116 & 2900 & 2.5 & 0.60 & 2.42 & 0.39 & 0.97 & 2.06 & 9.32 \\
\hline
\end{tabular}


Table 2 Continued

\begin{tabular}{|c|c|c|c|c|c|c|c|c|c|c|c|c|c|}
\hline \multirow{2}{*}{ 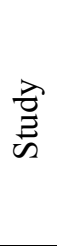 } & \multicolumn{2}{|c|}{$\begin{array}{l}\text { Column } \\
\text { geometric } \\
\text { properties }\end{array}$} & \multicolumn{2}{|c|}{$\begin{array}{l}\text { Concrete } \\
\text { properties }\end{array}$} & \multicolumn{4}{|c|}{ Fibre properties } & \multicolumn{3}{|c|}{ FRP properties } & \multicolumn{2}{|c|}{$\begin{array}{c}\text { Strength and } \\
\text { ductility } \\
\text { capacity }\end{array}$} \\
\hline & $\begin{array}{c}D \\
(\mathrm{~mm})\end{array}$ & $H / D$ & $\begin{array}{c}f_{c o} \\
(\mathrm{MPa})\end{array}$ & $\begin{array}{c}\varepsilon_{c o} \\
(\%)\end{array}$ & $\begin{array}{c}E_{f} \\
(\mathrm{GPa})\end{array}$ & $\begin{array}{c}f_{f u} \\
(\mathrm{MPa})\end{array}$ & $\begin{array}{c}\varepsilon_{f u} \\
(\%)\end{array}$ & $\begin{array}{c}t_{f} \\
(\mathrm{~mm})\end{array}$ & $\begin{array}{l}\varepsilon_{\text {rup }} \\
(\%)\end{array}$ & $\frac{f_{l, a}}{f_{c o}}$ & $k_{\varepsilon}$ & $\frac{f_{c c}^{\prime}}{f_{c o}}$ & $\frac{\varepsilon_{c u}}{\varepsilon_{c o}}$ \\
\hline \multirow{35}{*}{ 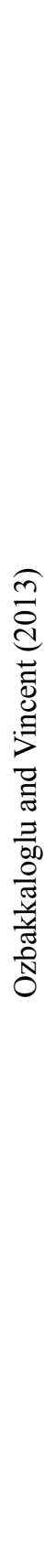 } & 150 & 2.0 & 79.6 & 0.30 & 116 & 2900 & 2.5 & 0.60 & 2.12 & 0.25 & 0.85 & 1.32 & 5.57 \\
\hline & 150 & 2.0 & 77.2 & 0.30 & 116 & 2900 & 2.5 & 0.60 & 1.59 & 0.19 & 0.64 & 1.32 & 5.47 \\
\hline & 150 & 2.0 & 77.0 & 0.30 & 116 & 2900 & 2.5 & 0.60 & 1.79 & 0.22 & 0.72 & 1.53 & 7.43 \\
\hline & 150 & 2.0 & 59.0 & 0.26 & 240 & 3800 & 1.6 & 0.23 & 1.14 & 0.14 & 0.72 & 1.16 & 3.65 \\
\hline & 150 & 2.0 & 59.0 & 0.26 & 240 & 3800 & 1.6 & 0.23 & 1.19 & 0.15 & 0.75 & 1.11 & 4.04 \\
\hline & 150 & 2.0 & 62.0 & 0.26 & 240 & 3800 & 1.6 & 0.23 & 1.03 & 0.12 & 0.65 & 1.08 & 3.23 \\
\hline & 150 & 2.0 & 59.0 & 0.26 & 240 & 3800 & 1.6 & 0.35 & 1.07 & 0.20 & 0.68 & 1.34 & 4.77 \\
\hline & 150 & 2.0 & 65.0 & 0.27 & 240 & 3800 & 1.6 & 0.35 & 0.77 & 0.13 & 0.49 & 1.20 & 4.81 \\
\hline & 150 & 2.0 & 59.0 & 0.26 & 240 & 3800 & 1.6 & 0.35 & 0.92 & 0.18 & 0.58 & 1.38 & 5.92 \\
\hline & 150 & 2.0 & 59.0 & 0.26 & 640 & 2650 & 0.4 & 0.19 & 0.26 & 0.07 & 0.63 & 1.19 & 1.92 \\
\hline & 150 & 2.0 & 55.6 & 0.25 & 640 & 2650 & 0.4 & 0.19 & 0.22 & 0.06 & 0.53 & 1.20 & 2.00 \\
\hline & 150 & 2.0 & 59.0 & 0.26 & 640 & 2650 & 0.4 & 0.19 & 0.26 & 0.07 & 0.63 & 1.18 & 1.81 \\
\hline & 150 & 2.0 & 59.0 & 0.26 & 640 & 2650 & 0.4 & 0.38 & 0.11 & 0.06 & 0.27 & 1.20 & 1.81 \\
\hline & 150 & 2.0 & 59.0 & 0.26 & 640 & 2650 & 0.4 & 0.38 & 0.14 & 0.08 & 0.34 & 1.31 & 1.73 \\
\hline & 150 & 2.0 & 59.0 & 0.26 & 640 & 2650 & 0.4 & 0.38 & 0.10 & 0.05 & 0.24 & 1.25 & 1.54 \\
\hline & 75 & 2.0 & 75.0 & 0.29 & 240 & 3800 & 1.6 & 0.12 & 0.62 & 0.06 & 0.39 & 1.15 & 2.28 \\
\hline & 75 & 2.0 & 77.0 & 0.30 & 240 & 3800 & 1.6 & 0.12 & 0.83 & 0.08 & 0.52 & 1.08 & 2.60 \\
\hline & 75 & 2.0 & 83.1 & 0.31 & 240 & 3800 & 1.6 & 0.23 & 0.95 & 0.17 & 0.60 & 1.17 & 4.23 \\
\hline & 75 & 2.0 & 83.1 & 0.31 & 240 & 3800 & 1.6 & 0.23 & 0.95 & 0.17 & 0.60 & 1.34 & 3.74 \\
\hline & 75 & 2.0 & 93.8 & 0.33 & 240 & 3800 & 1.6 & 0.35 & 0.85 & 0.20 & 0.54 & 1.51 & 3.91 \\
\hline & 75 & 2.0 & 99.9 & 0.34 & 240 & 3800 & 1.6 & 0.35 & 0.93 & 0.21 & 0.59 & 1.20 & 3.71 \\
\hline & 75 & 2.0 & 77.0 & 0.30 & 240 & 3800 & 1.6 & 0.35 & 0.73 & 0.21 & 0.46 & 1.71 & 3.80 \\
\hline & 75 & 2.0 & 82.5 & 0.31 & 240 & 3800 & 1.6 & 0.35 & 0.57 & 0.16 & 0.36 & 1.49 & 3.13 \\
\hline & 100 & 2.0 & 110.1 & 0.35 & 116 & 2900 & 2.5 & 0.60 & 1.35 & 0.17 & 0.54 & 1.41 & 6.03 \\
\hline & 100 & 2.0 & 110.1 & 0.35 & 116 & 2900 & 2.5 & 0.60 & 1.54 & 0.19 & 0.62 & 1.37 & 4.89 \\
\hline & 100 & 2.0 & 110.1 & 0.35 & 116 & 2900 & 2.5 & 0.60 & 1.78 & 0.23 & 0.71 & 1.42 & 5.34 \\
\hline & 100 & 2.0 & 110.1 & 0.35 & 116 & 2900 & 2.5 & 0.80 & 1.47 & 0.25 & 0.59 & 1.67 & 6.31 \\
\hline & 100 & 2.0 & 110.1 & 0.35 & 116 & 2900 & 2.5 & 0.80 & 1.57 & 0.26 & 0.63 & 1.73 & 7.06 \\
\hline & 100 & 2.0 & 110.1 & 0.35 & 116 & 2900 & 2.5 & 0.90 & 2.01 & 0.38 & 0.80 & 2.11 & 9.20 \\
\hline & 100 & 2.0 & 110.1 & 0.35 & 116 & 2900 & 2.5 & 0.90 & 2.11 & 0.40 & 0.84 & 2.04 & 8.03 \\
\hline & 100 & 2.0 & 110.1 & 0.35 & 116 & 2900 & 2.5 & 0.90 & 2.26 & 0.43 & 0.90 & 2.22 & 9.94 \\
\hline & 150 & 2.0 & 104.5 & 0.34 & 116 & 2900 & 2.5 & 1.20 & 1.19 & 0.21 & 0.48 & 1.57 & 5.82 \\
\hline & 150 & 2.0 & 104.5 & 0.34 & 116 & 2900 & 2.5 & 1.20 & 1.53 & 0.27 & 0.61 & 1.61 & 6.41 \\
\hline & 150 & 2.0 & 104.5 & 0.34 & 116 & 2900 & 2.5 & 1.20 & 1.63 & 0.29 & 0.65 & 1.71 & 6.03 \\
\hline & 150 & 2.0 & 94.7 & 0.33 & 240 & 3800 & 1.6 & 0.35 & 0.86 & 0.10 & 0.54 & 1.05 & 2.70 \\
\hline
\end{tabular}


Table 2 Continued

\begin{tabular}{|c|c|c|c|c|c|c|c|c|c|c|c|c|c|}
\hline \multirow{2}{*}{ 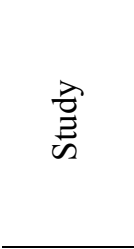 } & \multicolumn{2}{|c|}{$\begin{array}{l}\text { Column } \\
\text { geometric } \\
\text { properties }\end{array}$} & \multicolumn{2}{|c|}{$\begin{array}{l}\text { Concrete } \\
\text { properties }\end{array}$} & \multicolumn{4}{|c|}{ Fibre properties } & \multicolumn{3}{|c|}{ FRP properties } & \multicolumn{2}{|c|}{$\begin{array}{c}\text { Strength and } \\
\text { ductility } \\
\text { capacity }\end{array}$} \\
\hline & $\begin{array}{c}D \\
(\mathrm{~mm})\end{array}$ & $H / D$ & $\begin{array}{c}f_{c o} \\
(\mathrm{MPa})\end{array}$ & $\begin{array}{c}\varepsilon_{c o} \\
(\%)\end{array}$ & $\begin{array}{c}E_{f} \\
(\mathrm{GPa})\end{array}$ & $\begin{array}{c}f_{f u} \\
(\mathrm{MPa})\end{array}$ & $\begin{array}{c}\varepsilon_{f u} \\
(\%)\end{array}$ & $\begin{array}{c}t_{f} \\
(\mathrm{~mm})\end{array}$ & $\begin{array}{l}\varepsilon_{\text {rup }} \\
(\%)\end{array}$ & $\frac{f_{l, a}}{f_{c o}}$ & $k_{\varepsilon}$ & $\frac{f_{c c}^{\prime}}{f_{c o}}$ & $\frac{\varepsilon_{c u}}{\varepsilon_{c o}}$ \\
\hline \multirow{5}{*}{ 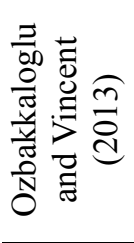 } & 150 & 2.0 & 93.0 & 0.33 & 240 & 3800 & 1.0 & 0.47 & 0.11 & 0.11 & 0.45 & 1.03 & 2.79 \\
\hline & 150 & 2.0 & 97.5 & 0.33 & 240 & 3800 & 1.6 & 0.47 & 0.97 & 0.15 & 0.61 & 1.10 & 3.06 \\
\hline & 150 & 2.0 & 102.5 & 0.34 & 240 & 3800 & 1.6 & 0.70 & 0.89 & 0.20 & 0.56 & 1.28 & 3.74 \\
\hline & 150 & 2.0 & 96.0 & 0.33 & 240 & 3800 & 1.6 & 0.70 & 0.78 & 0.18 & 0.49 & 1.29 & 3.52 \\
\hline & 150 & 2.0 & 93.0 & 0.33 & 240 & 3800 & 1.6 & 0.70 & 0.66 & 0.16 & 0.42 & 1.21 & 3.30 \\
\hline \multirow{16}{*}{ 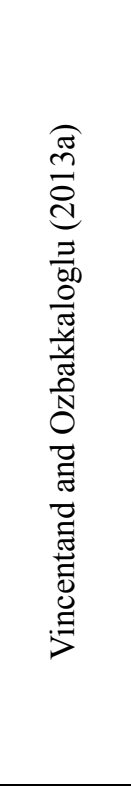 } & 152 & 2.0 & 35.5 & 0.20 & 240 & 3800 & 1.6 & 0.23 & 1.49 & 0.31 & 0.94 & 1.43 & 6.60 \\
\hline & 152 & 2.0 & 36.3 & 0.21 & 240 & 3800 & 1.6 & 0.23 & 1.55 & 0.32 & 0.98 & 1.53 & 6.48 \\
\hline & 152 & 2.0 & 37.3 & 0.21 & 240 & 3800 & 1.6 & 0.23 & 1.23 & 0.24 & 0.78 & 1.45 & 5.86 \\
\hline & 152 & 2.0 & 59.0 & 0.26 & 240 & 3800 & 1.6 & & 1.25 & 0.16 & 0.79 & 1.05 & 4.58 \\
\hline & 152 & 2.0 & 59.0 & 0.26 & 240 & 3800 & 1.6 & 0.35 & 1.24 & 0.23 & 0.78 & 1.24 & 4.12 \\
\hline & 152 & 2.0 & 65.0 & 0.27 & 240 & 3800 & 1.6 & 0.35 & 0.99 & 0.17 & 0.63 & 1.30 & 2.85 \\
\hline & 152 & 2.0 & 59.0 & 0.26 & 240 & 3800 & 1.6 & 0.35 & 0.98 & 0.18 & 0.62 & 1.54 & 3.54 \\
\hline & 152 & 2.0 & 59.0 & 0.26 & 240 & 3800 & 1.6 & 0.47 & 1.05 & 0.26 & 0.66 & 1.14 & 3.54 \\
\hline & 152 & 2.0 & 59.0 & 0.26 & 240 & 3800 & 1.6 & 0.47 & 1.06 & 0.27 & 0.67 & 1.36 & 3.77 \\
\hline & 152 & 2.0 & 59.0 & 0.26 & 240 & 3800 & 1.6 & 0.47 & 0.70 & 0.18 & 0.44 & 1.23 & 2.38 \\
\hline & 152 & 2.0 & 97.5 & 0.33 & 240 & 3800 & 1.6 & 0.47 & 1.15 & 0.17 & 0.13 & 1.01 & 2.94 \\
\hline & 152 & 2.0 & 102.5 & 0.34 & 240 & 3800 & 1.6 & 0.59 & 0.89 & 0.16 & 0.56 & 1.06 & 2.56 \\
\hline & 152 & 2.0 & 102.5 & 0.34 & 240 & 3800 & 1.6 & 0.59 & 0.81 & 0.15 & 0.51 & 1.01 & 2.18 \\
\hline & 152 & 2.0 & 102.5 & 0.34 & 240 & 3800 & 1.6 & 0.70 & 1.00 & 0.22 & 0.63 & 1.27 & 2.62 \\
\hline & 152 & 2.0 & 94.0 & 0.33 & 240 & 3800 & 1.6 & 0.70 & 0.84 & 0.20 & 0.53 & 1.16 & 2.36 \\
\hline & 152 & 2.0 & 93.0 & 0.33 & 240 & 3800 & 1.6 & 0.70 & 0.81 & 0.19 & 0.51 & 1.09 & 2.00 \\
\hline \multirow{9}{*}{ 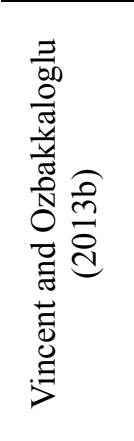 } & 100 & 2.0 & 85.9 & 0.31 & 99 & 2930 & 2.9 & 0.60 & 2.36 & 0.33 & 0.80 & 2.05 & 9.32 \\
\hline & 100 & 2.0 & 83.0 & 0.31 & 99 & 2930 & 2.9 & 0.60 & 1.74 & 0.25 & 0.59 & 1.87 & 8.16 \\
\hline & 100 & 2.0 & 85.9 & 0.31 & 99 & 2930 & 2.9 & 0.60 & 2.42 & 0.33 & 0.82 & 2.06 & 9.32 \\
\hline & 152 & 2.0 & 49.4 & 0.24 & 99 & 2930 & 2.9 & 0.60 & 2.19 & 0.35 & 0.74 & 2.12 & 13.13 \\
\hline & 152 & 2.0 & 49.4 & 0.24 & 99 & 2930 & 2.9 & 0.60 & 2.42 & 0.38 & 0.82 & 2.18 & 14.79 \\
\hline & 152 & 2.0 & 49.4 & 0.24 & 99 & 2930 & 2.9 & 0.60 & 2.38 & 0.38 & 0.80 & 2.15 & 14.46 \\
\hline & 152 & 2.0 & 49.4 & 0.24 & 99 & 2930 & 2.9 & 0.60 & 2.11 & 0.33 & 0.71 & 2.22 & 12.54 \\
\hline & 152 & 2.0 & 49.4 & 0.24 & 99 & 2930 & 2.9 & 0.60 & 2.33 & 0.37 & 0.79 & 2.22 & 13.25 \\
\hline & 152 & 2.0 & 49.4 & 0.24 & 99 & 2930 & 2.9 & 0.60 & 2.24 & 0.35 & 0.76 & 2.24 & 12.42 \\
\hline
\end{tabular}




\section{Main features of Circular CFFT Column Database}

The main features of various influencing parameters such as material properties of FRP tube, diameter of CFFT, unconfined concrete strength and height to diameter ratio of circular CFFT columns have been discussed herein to propose reliable design oriented strength and strain enhancement ratio models for circular CFFT columns.

\subsection{Diameter of circular CFFT columns}

In Table 2, the diameter of circular CFFT columns $(D)$ varies between 74 to $302 \mathrm{~mm}$ with the majority (55\%) of circular CFFT columns have diameter of 150-152 $\mathrm{mm}$. The strength and strain enhancement ratios of circular CFFT columns are not significantly influenced by the variation in the diameter of CFFT columns for the range of column diameters studied in this research. It is noted that column diameter is inversely proportional to actual confinement ratio (Eq. (4)). Hence, increase in the column diameter, keeping tube thickness the same, should decrease actual confinement ratio and consequently decrease the strength and strain enhancement ratios.

\subsection{Unconfined concrete strength}

In most of the studies included in this database, the effect of unconfined concrete strength $\left(f_{c o}\right)$ on the strength and strain enhancement ratios of circular CFFT columns was investigated. The unconfined concrete strength in this database varies between 34.0 and $110.1 \mathrm{MPa}$ with $35.1 \%$ of circular CFFT columns are within the range of 34.0 to $55 \mathrm{MPa}$ (Normal Strength Concrete, NSC, $f_{c o} \leq 55 \mathrm{MPa}$ ), while $32.8 \%$ are in the range of $>55$ to $85 \mathrm{MPa}$ (High Strength Concrete, HSC, 55 $>f_{c o} \leq 85 \mathrm{MPa}$ ) and $32.1 \%$ are greater than $85 \mathrm{MPa}$ (Ultra High Strength Concrete, UHSC, $f_{c o}>85$ $\mathrm{MPa}$ ). Almost all of the circular CFFT column studies reported that for a given nominal or actual confinement ratio, increase in unconfined concrete strength resulted in significant decrease in the strength and strain enhancement ratios of circular CFFT columns. Hence, more confinement reinforcement is required to sufficiently confine the circular CFFT columns constructed with HSC and UHSC than columns constructed with NSC to develop equivalent confinement pressures (Ozbakkaloglu 2013b, Vincent and Ozbakkaloglu 2013a). The unconfined concrete strength also has an inverse relationship to actual confinement ratio given by Eq. (4). In general, an increase in unconfined concrete strength results in decrease in confinement pressure $\left(f_{l}\right)$ hence reduction in actual confinement ratio $\left(f_{l, a} / f_{c o}\right)$. The reduction in actual confinement ratio or the increase in concrete brittleness results in reduction in the strength and strain enhancement ratios of circular CFFT columns. Increased concrete brittleness also changes the concrete crack patterns from heterogeneous micro-cracks to localized macro-cracks.

\subsection{Height to diameter ratio}

In the circular CFFT columns database height to diameter ratio of data points lies within a range of 2.0 to 2.85 with $95.5 \%$ with height to diameter ratio of 2.0 . An increase in height to diameter ratio from 2.0 to 2.85 does not have any significant influence on the strength and strain enhancement ratios. However, Mohamed and Masmoudi (2008b) stated that height to diameter ratio of circular CFFT columns greater than 6.0 may significantly reduce the strength enhancement ratio of circular CFFT columns due to buckling phenomenon. 


\subsection{Orientation of fibres}

The orientation of fibres in FRP tube influences the strength and strain enhancement ratios of circular CFFT columns (Vincent and Ozbakkaloglu 2013b). The larger the proportion of fibres orientated along the circumferential direction will create larger confinement pressure $\left(f_{l}\right)$, which may result in an increase in the strength and strain enhancement ratios. All the circular CFFT column data points in this database have the fibres orientated along the circumferential direction with the final failure due to rupture of fibres in the mid-height of circular CFFT columns. Hence, the orientation of fibres has not been considered in the developed design oriented models. Also, the effect of orientation of fibres may have been taken into account with the circumferential rupture strain of fibres $\left(\varepsilon_{\text {rup }}\right)$.

\subsection{Actual confinement ratio}

In the circular CFFT database presented in this paper, the actual confinement ratio $\left(f_{l, a} / f_{c o}\right)$ varies from 0.04 to 0.73 with most of the data points having a value less than 0.5 . The actual confinement ratio has a linear relationship with the strength and strain enhancement ratios of circular CFFT columns as shown in Figs. 2-3. However, scatter of data points in case of actual confinement ratio versus strain enhancement ratio is more than that observed in case of actual confinement ratio versus strength enhancement ratio.

In this study, the circumferential rupture strain $\left(\varepsilon_{r u p}\right)$ of circular CFFT columns is used instead of ultimate tensile strain of fibres $\left(\varepsilon_{f u}\right)$ to calculate actual confinement ratios (Eq. (4)) which are further used to develop design oriented models. The circumferential rupture strain is the experimental rupture strain of fibres attained during the testing of FRP confined concrete columns, whereas the ultimate tensile strain of fibres is a manufacturer provided or flat coupon tested value of strain of the fibres. The circumferential rupture strains are usually smaller than the ultimate tensile strains of fibres. This reduction in strain is due to manufacturing and construction errors, and complex material behaviour of concrete and FRP (Ozbakkaloglu and Lim 2013). The ratio of circumferential rupture strain $\left(\varepsilon_{r u p}\right)$ and the ultimate tensile strain $\left(\varepsilon_{f u}\right)$ of fibres is defined as strain reduction factor $\left(k_{\varepsilon}\right)($ Eq. (13))

$$
k_{\varepsilon}=\frac{\varepsilon_{r u p}}{\varepsilon_{f u}}
$$

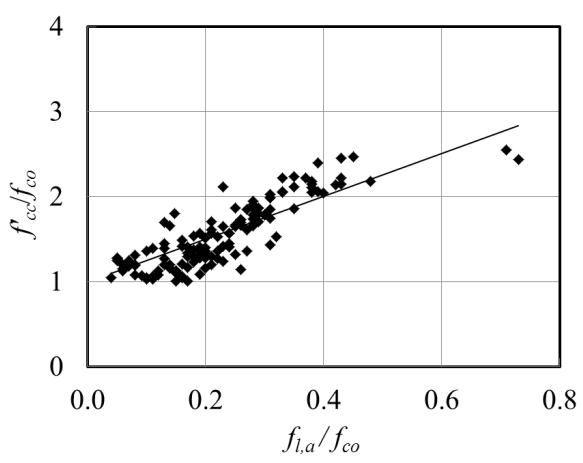

Fig. 2 Influence of actual confinement ratio $\left(f_{l, a} / f_{c o}\right)$ on strength enhancement ratio $\left(f_{c c}^{\prime} / f_{c o}\right)$ of circular CFFT columns in Table 2 


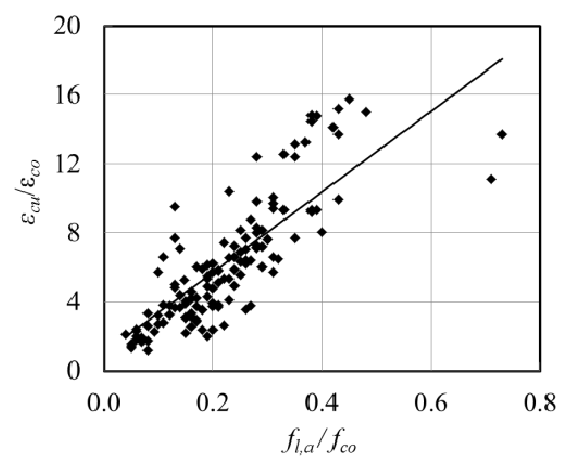

Fig. 3 Influence of actual confinement ratio $\left(f_{l, a} / f_{c o}\right)$ on strain enhancement ratio $\left(\varepsilon_{c u} / \varepsilon_{c o}\right)$ of circular CFFT columns in Table 2

In this study, the $k_{\varepsilon}$ for circular CFFT columns varies from 0.23 to 0.98 (Table 2). The average strain reduction factors for CFRP, AFRP, HMCFRP and GFRP CFFT columns have been found as $0.62,0.75,0.39$ and 0.85 with standard deviations of $0.15,0.12,0.14$ and 0.13 , respectively. The average strain reduction factor for CFFT columns included in this CFFT database is 0.66 with a standard deviation of 0.17 . These $k_{\varepsilon}$ values are similar to the $k_{\varepsilon}$ values proposed for FRP confined concrete columns in Ozbakkaloglu and Lim (2013). The $k_{\varepsilon}$ expression for circular CFFT columns based on regression analyses of 134 circular CFFT columns with coefficient of determination $\left(R^{2}\right)$ of 0.51 has been proposed as given in Eq. (14)

$$
k_{\varepsilon}=1.03-0.0027 f_{c o}-0.00085 E_{f}
$$

where $f_{c o}$ is the unconfined concrete strength in $\mathrm{MPa}$ and $E_{f}$ is the modulus of elasticity of fibres in $\mathrm{GPa}$. The average, minimum and maximum values of all the input and output parameters included in this circular CFFT column database (Table 2) are presented in Table 3.

\section{Behaviour of circular CFFT under concentric loading}

The circular CFFT column database in Table 2 is used to develop design oriented models for the strength and strain enhancement ratios of circular CFFT columns. The Eq. (15) was proposed by Richart et al. (1928) for a simple linear relationship between nominal confinement ratio $\left(f_{l} / f_{c o}\right)$ and strength enhancement ratio $\left(f_{c c}^{\prime} / f_{c o}\right)$ (Eq. (15)).

$$
\frac{f_{c c}^{\prime}}{f_{c o}}=1+k_{1}\left(\frac{f_{l}}{f_{c o}}\right)
$$

where $k_{1}$ the confinement effectiveness

Saaman et al. (1998), Saafi et al. (1999), Lam and Teng (2002) and Ozbakkaloglu and Lim (2013) and Lim and Ozbakkaloglu (2014) also used Eq. (15) with different $k_{l}$ values to develop design oriented models for FRP confined concrete columns. To improve the accuracy of the proposed design oriented model to determine the strength enhancement ratio $\left(f_{c c}^{\prime} / f_{c o}\right)$, the nominal 
confinement ratio $\left(f_{l} / f_{c o}\right)$ in Eq. (15) has been replaced with actual confinement ratio $\left(f_{l, a} / f_{c o}\right)$ as given in Eq. (16).

$$
\frac{f_{c c}^{\prime}}{f_{c o}}=1+k_{1}\left(\frac{f_{l, a}}{f_{c o}}\right)
$$

Ozbakkaloglu et al. (2012) reported that most of the existing ultimate strain enhancement relationships proposed nonlinear forms to predict strain enhancement ratio as a function of actual confinement ratio $\left(f_{l, a} / f_{c o}\right)$.

The actual confinement ratio includes almost all of the important parameters that influence the behaviour of circular CFFT columns. As all of circular CFFT columns have orientation of fibres along the circumferential direction so orientation of fibre has not been considered in the developed models. The actual confinement ratio (Eq. 4) does not include the height to diameter ratio $(H / D)$ ratio. The compiled database contains CFFT columns with $H / D$ ratio varying from 2.0 to 2.85 with $95.5 \%$ of the columns having $H / D$ ratio of 2.0 . However, $H / D$ does not significantly influence the strength and strain enhancement ratios of circular CFFT columns for the range of $H / D$ of circular CFFT columns included in this database.

\subsection{Regression analyses of circular CFFT column database}

Regression Analyses of circular CFFT database is carried out to propose design oriented models to determine the strength and strain enhancement ratios. The verification of the proposed models is carried out using the four statistical indicators, i.e., Average Absolute Error (AAE), Mean Square Error (MSE), Relative Standard Error of Estimate (RSEE) and Standard Deviation (SD), as expressed in Eqs. (17)-(20).

$$
\begin{gathered}
A A E=\frac{\sum_{i=1}^{n=N}\left|\frac{\operatorname{Pr} e .(i)-\operatorname{Exp} .(i)}{\operatorname{Exp} .(i)}\right|}{N} \\
M S E=\frac{\sum_{i=1}^{n=N}\left(\frac{\operatorname{Pr} e .(i)-\operatorname{Exp} .(i)}{\operatorname{Exp} .(i)}\right)^{2}}{N} \\
R S E E=\frac{\sqrt{\sum_{i=1}^{n=N} \frac{(\operatorname{Exp} .(i)-\operatorname{Pr} e .(i))}{N-2}}}{\sum_{i=1}^{n} \operatorname{Exp} .(i)} \\
S D=\sqrt{\frac{\sum_{i=1}^{n=N}\left(\frac{\operatorname{Pr} e .(i)}{\operatorname{Exp} .(i)}-\frac{\operatorname{Pr} e .(\text { avg. })}{\operatorname{Exp} .(\text { avg. })}\right.}{N-1}}
\end{gathered}
$$


where Pre. is the Model prediction, Exp. is the Experimental Test Database and $N$ is the total number of test data points. The statistical parameters are expressed in percentage.

\subsection{Prediction of the strength enhancement ratio for circular CFFT columns}

A design oriented model to determine the strength enhancement ratio of circular CFFT columns as a function of actual confinement ratio $\left(f_{l, a} / f_{c o}\right)$ is proposed in Eq. (21). The strength enhancement ratio increases with an increase in actual confinement ratio. The confinement effectiveness $\left(k_{1}\right)$ value for strength enhancement ratio has been found as 2.52 with coefficient of determination $\left(R^{2}\right)$ of 0.72 (Eq. (22)).

$$
\frac{f_{c c}^{\prime}}{f_{c o}}=1.0+2.52\left(\frac{f_{l, a}}{f_{c o}}\right)
$$

The CFFT database consisting of 134 data points was used to assess the performance of the existing strength enhancement ratio models developed in Lam and Teng (2002) (Eq. (1)) (Fig. (4)) and Ozbakkaloglu and Lim (2013) and Lim and Ozbakkaloglu (2014) (Eq. (6)) (Fig. 5) and the proposed strength enhancement ratio model (Eq. (21)) (Fig. 6). The comparison between the test results and the predictions shows the improvement of the proposed model in calculating the strength enhancement ratio of circular CFFT columns. Among the presented strength enhancement ratio models, the proposed strength enhancement ratio model has the largest coefficient of determination $\left(R^{2}\right)$ of 0.72 . In addition, the errors of the proposed and the existing strength enhancement ratio models were statistically verified (Fig. 7).

It is evident from Fig. 7 that, the proposed strength enhancement ratio model shows significantly smaller statistical errors than Lam and Teng (2002) and Ozbakkaloglu and Lim (2013) and Lim and Ozbakkaloglu (2014) strength enhancement ratio models. This is attributed to the fact that the proposed model was developed from larger number of data points. Also, it is noted that strength enhancement ratio model proposed by Ozbakkaloglu and Lim (2013) and Lim and Ozbakkaloglu (2014) performs better than Lam and Teng (2002) strength enhancement ratio model as Ozbakkaloglu and Lim (2013) and Lim and Ozbakkaloglu (2014) strength enhancement ratio models incorporate actual confinement ratio $\left(f_{l, a} / f_{c o}\right)$ as an input parameter. Lam and Teng (2002) strength enhancement ratio model considered nominal confinement ratio $\left(f_{l} / f_{c o}\right)$ as an input parameter.

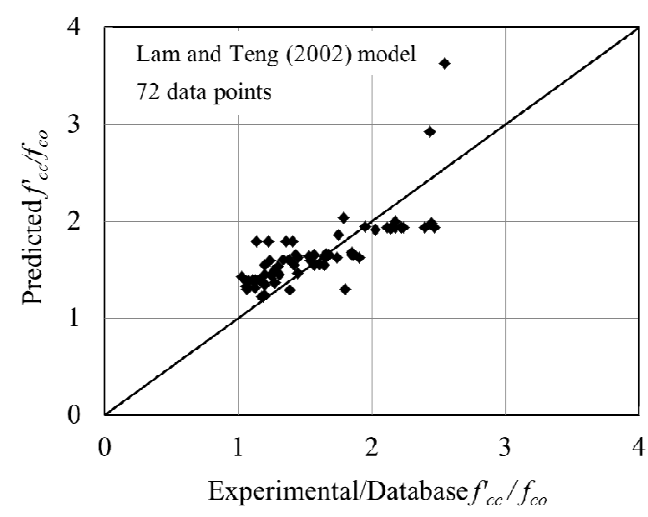

Fig. 4 The performance of Lam and Teng (2002) strength enhancement ratio model 


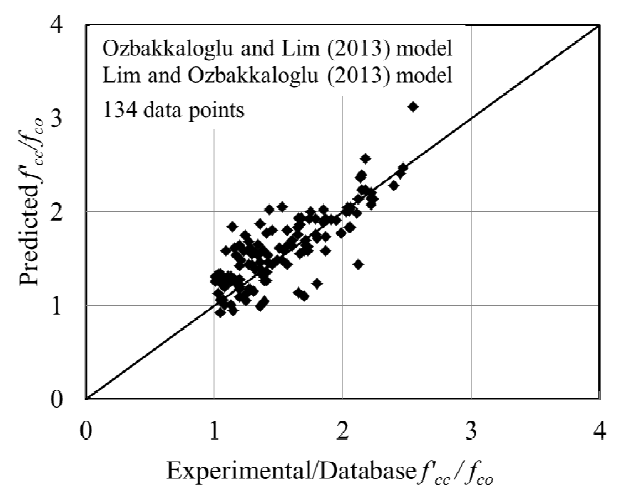

Fig. 5 The performance of Ozbakkaloglu and Lim (2013) and Lim and Ozbakkaloglu (2014) strength enhancement ratio model

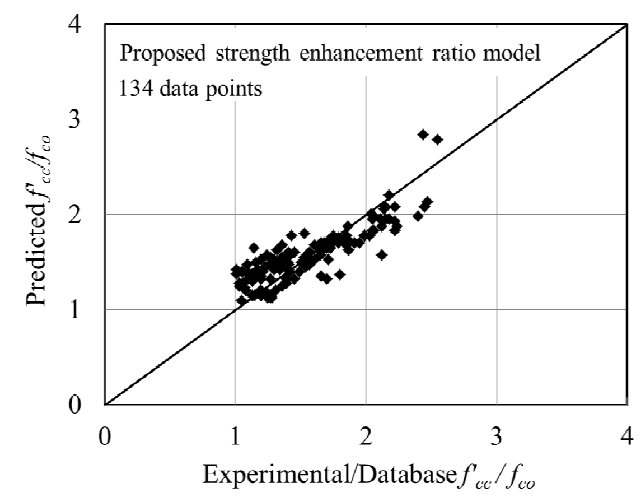

Fig. 6 The performance of proposed strength enhancement ratio model

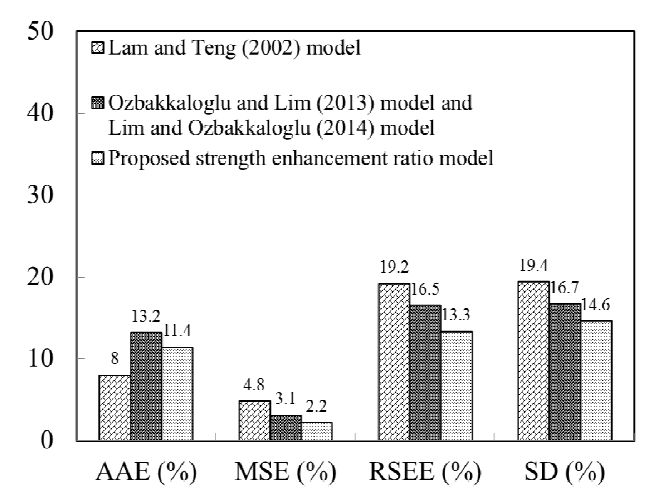

Fig. 7 Statistical comparison of the proposed and selected strength enhancement ratio models

\subsection{Prediction of the strain enhancement ratio of circular CFFT columns}

A design oriented model to determine the strain enhancement ratio $\left(\varepsilon_{c u} / \varepsilon_{c o}\right)$ of circular CFFT columns as a function of actual confinement ratio $\left(f_{l, a} / f_{c o}\right)$ and confinement modulus $\left(K_{l}\right)$ is proposed with coefficient of determination $\left(R^{2}\right)$ of 0.80 (Eq. (22)). 


$$
\frac{\varepsilon_{c u}}{\varepsilon_{c o}}=1+685.1\left(\frac{f_{l, a}}{f_{c o}}\right)^{1.126} K_{l}^{-0.461}
$$

The performance of the existing strain enhancement ratio models presented in De Lorenzis and Tepfers (2003) (Eq. (3)) (Fig. 8) and Ozbakkaloglu and Lim (2013) and Lim and Ozbakkaloglu (2014) (Eq. (11)) (Fig. 9) and the proposed strain enhancement ratio model (Eq. (22)) (Fig. 10) were assessed using the CFFT database consisting of 134 data points.

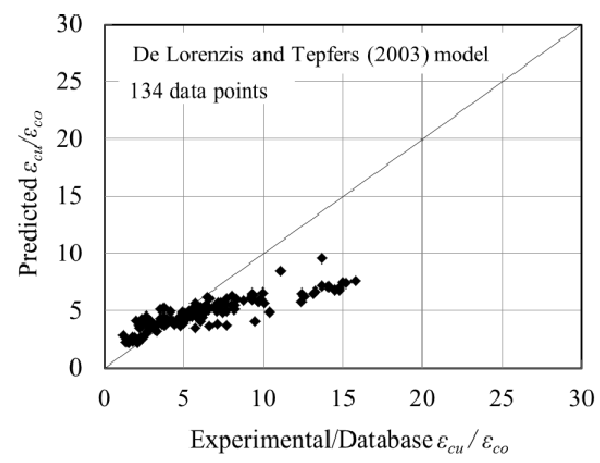

Fig. 8 Performance of the De Lorenzis and Tepfers (2003) strain enhancement ratio model

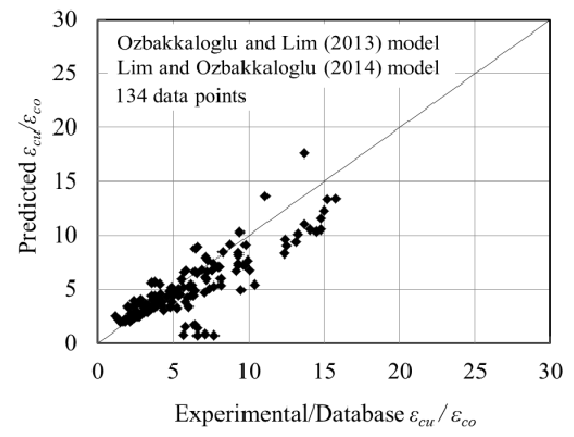

Fig. 9 Performance of the Ozbakkaloglu and Lim (2013) and Lim and Ozbakkaloglu (2014) strain enhancement ratio model

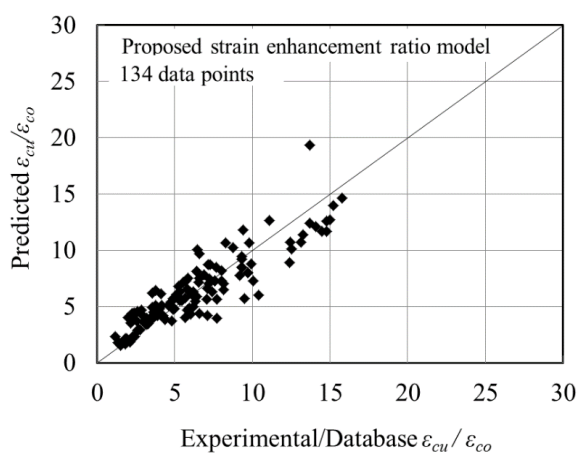

Fig. 10 Performance of the proposed strain enhancement ratio model 


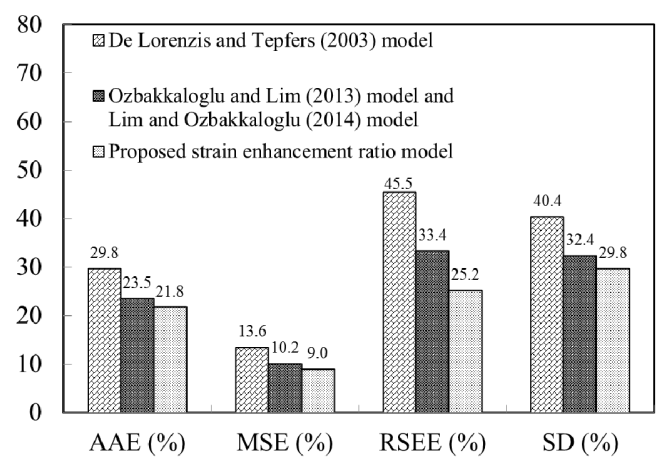

Fig. 11 Statistical comparison of the proposed and selected strain enhancement ratio models

The comparison between the test results and the predictions show the improvement of the proposed model in calculating the strain enhancement ratio of circular CFFT columns. Among the presented strain enhancement ratio models, the proposed model has the largest coefficient of determination $\left(R^{2}\right)$ of 0.80 . Also, the error of the existing and proposed strain enhancement ratio models was statistically verified (Fig. 11).

The proposed strain enhancement ratio model has exhibited smaller statistical errors than De Lorenzis and Tepfers (2003) and Ozbakkaloglu and Lim (2013) and Lim and Ozbakkaloglu (2014) strain enhancement ratio models (Fig. 11). It is noted that strain enhancement ratio model proposed by Ozbakkaloglu and Lim (2013) and Lim and Ozbakkaloglu (2014) has exhibited smaller statistical errors than De Lorenzis and Tepfers (2003) strain enhancement ratio model as Ozbakkaloglu and Lim (2013) and Lim and Ozbakkaloglu (2014) strain enhancement ratio models was validated with larger number of FRP confined concrete columns as compared to De Lorenzis and Tepfers (2003).

\subsection{Experimental versus predictions}

The Fig. 12 compares the results of the proposed design oriented strength enhancement ratio model and the experimental strength enhancement ratios of CFFT columns compiled in Table 2.

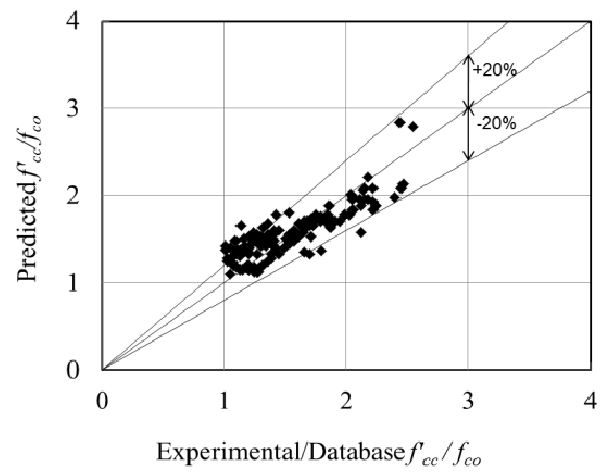

Fig. 12 Perimental/Database versus the proposed model predictions for the strength enhancement ratio $\left(f_{c c}^{\prime} / f_{c o}\right)$ 


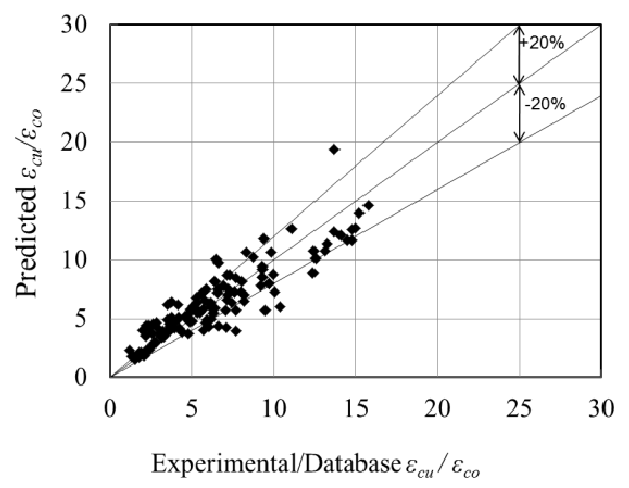

Fig. 13 Experimental/Database versus the proposed model predictions for the strain enhancement ratio $\left(\varepsilon_{c u} / \varepsilon_{c o}\right)$

The predictions of the proposed strength enhancement ratio model and the experimental strength enhancement ratios match well with $85 \%$ of data are within $\pm 20 \%$ of the predicted strength enhancement ratio values.

The Fig. 13 compares the results of the proposed design oriented strain enhancement ratio model and the experimental strain enhancement ratios of CFFT columns compiled in Table 2. For the prediction of the proposed strain enhancement ratio model, more than $70 \%$ of data fall within $\pm 20 \%$ of the predicted strain enhancement ratio values.

It is noted that the strength and strain enhancement ratios are significantly influenced by unconfined concrete strength and material properties of fibres. The actual confinement ratio decreases with increase in the unconfined concrete strength. Hence, to achieve equivalent confinement ratios, HSC and UHSC filled FRP tube columns require either larger tube thicknesses or higher modulus of fibres than NSC filled FRP tube columns. The properties of FRP tubes may significantly influence the predicted values.

\section{Conclusions}

This paper presents a comprehensive database of experimental test results of circular CFFT columns. Based on predefined selection criteria, 134 circular CFFT column test results (database) from 599 CFFT specimen test results have been compiled. Also, different parameters (diameter of CFFT, height to diameter ratio of columns, unconfined concrete strength, and actual confinement ratio) that influence the behaviour of circular CFFT columns have been investigated. Design oriented models to predict the strength and strain enhancement ratios of circular CFFT column have been proposed. Following conclusions are drawn based on the compilation of the circular CFFT column database and on the development of design oriented models.

The strength and strain enhancement ratios of circular CFFT columns significantly depend on the actual confinement ratio and increase linearly with an increase in the actual confinement ratio. The actual confinement ratio is expressed as a function of diameter of CFFT $(D)$, unconfined concrete strength $\left(f_{c o}\right)$, and modulus of elasticity of fibres $\left(E_{f}\right)$, thickness of fibre $\left(t_{f}\right)$ and actual circumferential rupture strain $\left(\varepsilon_{\text {rup }}\right)$ of the fibres.

Design oriented models developed to predict the strength and strain enhancement ratios of 
circular CFFT columns as a function of actual confinement ratio have smaller Average Absolute Error (AAE), Mean Square Error (MSE), Relative Standard Error of Estimate (RSEE) and Standard Deviation (SD) than the available strength and strain enhancement ratio models that are mainly developed for FRP confined concrete columns. The AAE, MSE, RSEE and SD of the proposed strength enhancement ration model are $11.4 \%, 2.4 \%, 13.3 \%$ and $14.6 \%$, respectively. The AAE, MSE, RSEE and SD of the proposed strain enhancement ratio model are $21.8 \%, 9.0 \%$, $25.2 \%$ and $29.8 \%$, respectively.

The results of the proposed strength and strain enhancement ratio models match well with the experimental strength and strain enhancement ratios of circular CFFT database. More than $85 \%$ of data points fall within $\pm 20 \%$ of the predictions by the strength enhancement ratio model and $70 \%$ data points fall within $\pm 20 \%$ of the predictions by the strain enhance ratio model.

\section{Acknowledgments}

The authors thank the University of Wollongong, Australia for research facilities. The first author thanks the University of Engineering and Technology, Lahore and Higher Education Commission (HEC) of Pakistan, and the University of Wollongong, Australia for funding his $\mathrm{PhD}$ studies.

\section{References}

Aslani, F., Uy, B., Tao, Z. and Mashiri, F. (2015), "Predicting the axial load capacity of high-strength concrete filled steel tubular columns", Steel Compos. Struct., Int. J., 19(4), 967-99.

Berthet, J., Ferrier, E. and Hamelin, P. (2005), "Compressive behaviour of concrete externally confined by composite jackets. Part A: Experimental study", Construct. Build. Mater., 19(3), 223-232.

Choi, K. and Xiao, Y. (2010), "Analytical studies of concrete-filled circular steel tubes under axial compression", J. Struct. Eng., 136(5), 565-573.

Cole, B. and Fam, A. (2006), "Flexural load testing of concrete-filled FRP tubes with longitudinal steel and FRP rebar", J. Compos. Construct., 10(2), 161-171.

De Lorenzis, L. and Tepfers, R. (2003), “Comparative study of models on confinement of concrete cylinders with Fiber-Reinforced Polymer composites”, J. Compos. Construct., 7(3), 219-237.

Demers, M. and Neale, K. (1994), "Strengthening of concrete columns with unidirectional composite sheets", Develop. Short Medium Span Bridge Eng., 94, 895-905.

Fam, A. and Rizkalla, S. (2001a), "Concrete filled FRP tubes for flexural and axial compression members", Proceedings of ACMBS-3, 315-322.

Fam, A.Z. and Rizkalla, S.H. (2001b), "Behaviour of axially loaded concrete filled circular fiber reinforced polymer tubes", ACI Struct. J., 98(3), 280-289.

Fam, A. and Rizkalla, S. (2002), "Flexural behavior of concrete-filled fiber-reinforced polymer circular tubes", J. Compos. Construct., 6(2), 123-132.

Fam, A., Schnerch, D. and Rizkalla, S. (2005), "Rectangular filament-wound Glass Fiber Reinforced Polymer tubes filled with concrete under flexural and axial loading: Experimental investigation", $J$. Compos. Construct., 9(1), 25-33.

Hadi, M.N.S., Wang, W. and Sheikh, M.N. (2015), “Axial compressive behaviour of GFRP tube reinforced concrete columns", Construct. Build. Mater., 81, 198-207.

Hadi, M.N.S., Khan, Q.S. and Sheikh, M.N. (2016), "Axial and flexural behavior of unreinforced and FRP bar reinforced circular concrete filled FRP tube columns", Construct. Build. Mater., 122, 43-53.

Han, L., Yao, G. and Zhao, X. (2004), "Behaviour and calculation on concrete-filled steel CHS (Circular 
Hollow Section) beam-columns", Steel Compos. Struct., Int. J., 4(3), 169-188.

Harries, K.A. and Carey, S.A. (2002), "Shape and gap effects on the behaviour of variably confined concrete", Cement Concrete Res., 33(6), 881-890.

Hong, W.K. and Kim, H.C. (2004), "Behaviour of concrete columns confined by carbon composites tubes", Can. J. Civil Eng., 31(2), 178-188.

Idris, Y. and Ozbakkaloglu, T. (2013), "Seismic behavior of high-strength concrete-filled FRP tube columns", J. Compos. Construct., 17(6), 04013013.

Ishizawa, T., Nakano, T. and Iura, M. (2006), "Experimental study on partially concrete-filled steel tubular columns", Steel Compos. Struct., Int. J., 6(1), 55-69.

Johannson, M. (2003), "Composite action in connection regions of concrete-filled steel tube columns", Steel Compos. Struct., Int. J., 3(1), 47-64.

Jolly, C.K. and Lillistone, D. (1998a), "Concrete filled FRP circular columns under eccentric loading", Proceedings of the 7th International conference on Fibre Reinforced Composites, (P.A.G Gibson Ed.), Woodhead Publishing Ltd., University of Newcastle upon Tyne, UK.

Jolly, C.K. and Lillistone, D. (1998b), "The stress strain behaviour of concrete confined by advanced fiber composites", Proceedings of the 8th BCA Annual Conference on Higher Education and the Concrete Industry, (U.o. Southampton Ed.), England, UK, July.

Karbhari, V. and Gao, Y. (1997), "Composite jacketed concrete under uniaxial compression-verification of simple design equations", J. Mater. Civil Eng., 9(4), 185-193.

Lam, L. and Teng, J. (2002), "Strength models for fiber-reinforced plastic-confined concrete", J. Struct. Eng., 128(5), 612-623.

Lam, L. and Teng, J.G. (2003), "Design-oriented stress-strain model for FRP-confined concrete", Construct. Build. Mater., 17(6-7), 471-489.

Lee, S. (2007), "Capacity and the moment-curvature relationship of high strength concrete filled steel tube columns under eccentric loads", Steel Compos. Struct., Int. J., 7(2), 135-160.

Li, y., Yan, X. and Ou, J.P. (2007), "Compressive behaviour and non linear analysis of self sensing concrete filled FRP tubes and FRP steel Composite tubes", Proceedings of the 8th International Symposium on Fiber Reinforced Polymer Reinforcement for Concrete Structures, Patras, Greece, July.

Lillistone, D. and Jolly, C.K. (1997), "Concrete filled fibre reinforced plastic circular columns", Proceedings of Composite Construction-Conventional and Innovative Conference, Composite Construction-Conventional and Innovative, Innsbruck, Austria, September.

Lillistone, D. and Jolly, C.K. (2000), "An innovative form of reinforcement for concrete columns using advanced composites", The Struct. Eng., 78(23-24), 20-29.

Lim, J.C. and Ozbakkaloglu, T. (2014), "Confinement model for FRP-confined high-strength concrete", $J$. Compos. Construct., 18(4), 04013058.

Masmoudi, R. and Mohamed, H. (2011), “Axial behaviour of slender concrete filled FRP tube columns reinforced with steel and carbon FRP bars", Proceedings of the 10th International Symposium on FiberReinforced Polymer Reinforcement for Concrete Structures, Tampa, FL, USA, April.

Mastrapa, J.C. (1997), "Effect of construction bond on confinement with fibre composites", Masters; University of Florida, FL, USA.

Matthys, S., Taerwe, L. and Audenaert, K. (1999), “Tests on axially loaded concrete columns confined by fibre reinforced polymer sheet wrapping”, In: (C.W. Dolan, S.H. Rizkalla, A. Nanni Ed.), FRPRCS-4, American Concrete Institute, MI, USA.

Mirmiran, A. and Shahawy, M. (1996), “A new concrete-filled hollow FRP composite column”, Compos. Part B: Eng., 27(3-4), 263-268.

Mirmiran, A. and Shahawy, M. (1997), "Behaviour of concrete columns confined by fiber composites", $J$. Struct. Eng., 123(5), 583-590.

Mirmiran, A., Samaan, M., Cabrera, S. and Shahawy, M. (1998a), "Design, manufacture and testing of a new hybrid column", Construct. Build. Mater., 12(1), 39-49.

Mirmiran, A., Shahawy, M. and Samaan, M. (1998b), "Strength and ductility of hybrid FRP-concrete beamcolumns", J. Struct. Eng., 125(10), 1085-1093. 
Mirmiran, A., Shahawy, M., Samaan, M., EL Echary, H., Mastrapa, J.C. and Pico, O, (1998c), "Effect of column parameters on FRP confined concrete", J. Compos. Construct., 2(4), 175-185.

Mohamed, H. and Masmoudi, R. (2008a), "Behavior of the concrete filled FRP tube columns under eccentric load", Structural Composites for Infrastructure Applications (MESC-5), Hurghada, Egypt.

Mohamed, H. and Masmoudi, R. (2008b), "Compressive behaviour of reinforced concrete filled FRP tubes", Special Publication, 257, 91-108.

Mohamed, H. and Masmoudi, R. (2010), "Axial load capacity of concrete-Filled FRP tube columns: Experimental versus theoretical predictions", J. Compos. Construct., 14(2), 231-243.

Nanni, A. and Bradford, N.M. (1995), "FRP jacketed concrete under uniaxial compression", Construct. Build. Mater., 9(2), 115-124.

Ozbakkaloglu, T. (2013a), "Axial compressive behavior of square and rectangular high-strength concretefilled FRP tubes", J. Compos. Construct., 17(1), 151-161.

Ozbakkaloglu, T. (2013b), "Compressive behavior of concrete-filled FRP tube columns: Assessment of critical column parameters", Eng. Struct., 51, 188-199.

Ozbakkaloglu, T. and Lim, J.C. (2013), "Axial compressive behaviour of FRP confined concrete: Experimental test database and a new design oriented model", Compos. Part B: Eng., 55, 607-634.

Ozbakkaloglu, T. and Oehlers, D. (2008a), "Concrete-filled square and rectangular FRP tubes under axial compression", J. Compos. Construct., 12(4), 469-477.

Ozbakkaloglu, T. and Oehlers, D.J. (2008b), "Manufacture and testing of a novel FRP Tube confinement system", Eng. Struct., 30(9), 2448-2459.

Ozbakkaloglu, T. and Saatcioglu, M. (2006), "Seismic behavior of high-strength concrete columns confined by fiber-reinforced polymer tubes", J. Compos. Construct., 10(6), 538-549.

Ozbakkaloglu, T. and Vincent, T. (2013), "Axial compressive behavior of circular high-strength concretefilled FRP tubes", J. Compos. Construct., 18(2), 04013037-1-11.

Ozbakkaloglu, T., Lim, J.C. and Vincent, T. (2012), "FRP confined concrete in circular sections: Review and assessment of stress strain models", Eng. Struct., 49, 1068-1088.

Park, J.W. and Choi, S.M. (2013), "Structural behaviour of CFRP strengthened concrete-filled steel tubes columns under axial compression loads", Steel Compos. Struct., Int. J., 14(5), 453-472.

Park, J.H., Jo, B.W., Yoon, S.J. and Park, S.K. (2011), "Experimental investigation on the structural behaviour of concrete filled FRP tubes with/without steel rebar", KSCE J. Civil Eng., 15(2), 337-345.

Pham, T. and Hadi, M. (2013), "Strain estimation of CFRP-confined concrete columns using energy approach", J. Compos. Construct., 17(6), 04013001.

Pham, T. and Hadi, M. (2014a), "Predicting stress and strain of FRP-confined square/rectangular columns using artificial neural networks", J. Compos. Construct., 18(6), 04014019.

Pham, T. and Hadi, M. (2014b), "Stress prediction model for FRP confined rectangular concrete columns with rounded corners", J. Compos. Construct., 18(1), 04013019.

Realfonzo, R. and Napoli, A. (2011), "Concrete confined by FRP systems: Confinement efficiency and design strength models", Compos. Part B: Eng., 42(4), 736-755.

Richart, F.E., Brandtzaeg, A. and Brown, R.L. (1928), "A study of the failure of concrete under combined compressive stresses", University of Illinois Bulletin; University of Illinois, Urbana, IL, USA.

Saafi, M., Toutanji, H.A. and Li, Z. (1999), "Behaviour of concrete columns confined with fiber reinforced polymer tubes”, ACI Mater. J., 96(4), 500-509.

Saaman, M., Mirmiran, A. and Shahawy, M. (1998), "Model of concrete confined by fibre composites", Journal of Structural Engineering, 124(9), 1025-1031.

Sadeghian, P. and Fam, A. (2015), "Improved design-oriented confinement models for FRP-wrapped concrete cylinders based on statistical analyses", Eng. Struct., 87, 162-182.

Sakino, K., Nakahara, H., Morino, S. and Nishiyama, I. (2004), "Behavior of centrally loaded concrete-filled steel-tube short columns", J. Struct. Eng., 130(2), 180-188.

Tegola, L.A. and Manni, D. (1999), "Experimental investigation on concrete confined by fibre reinforced polymer and comparisons with theoretical model”, In: (C.W. Dolan, S.H. Rizkalla, A. Nanni Ed.), FRPRCS-4; American Concrete Institute, MI, USA. 
Toutanji, H.A. (1999), "Stress-strain characteristics of concrete columns externally confined with advanced fibre composite sheets", ACI Mater. J., 96(3), 397-404.

Vincent, T. and Ozbakkaloglu, T. (2013a), "Influence of concrete strength and confinement method on axial compressive behaviour of FRP confined high and ultra high strength concrete", Compos. Part B: Eng., 50, 413-428.

Vincent, T. and Ozbakkaloglu, T. (2013b), "Influence of fibre orientation and specimen end condition on axial compressive behaviour of FRP confined concrete", Construct. Build. Mater., 47, 814-826.

Woo, P.J., Kyun, H.Y. and Mo, C.S. (2010), "Behaviours of concrete filled square steel tubes confined by carbon fiber sheets (CFS) under compression and cyclic loads", Steel Compos. Struct., Int. J., 10(2), 187205.

Wu, G., Lu, Z. and Wu, Z. (2006), "Strength and ductility of concrete cylinders confined with FRP composites”, J. Construct. Build. Mater., 20(3), 134-138.

Wu, Y.F. and Jiang, C. (2013), "Effect of load eccentricity on the stress-strain relationship of FRP-confined concrete columns", Compos. Struct., 98, 228-241.

Yamakawa, T., Zhong, P. and Ohama, A. (2003), "Seismic performance of aramid fiber square tubed concrete columns with metallic and/or non-metallic reinforcement", J. Reinf. Plast. Compos., 22(13), 1221-1238.

Youssef, M., Feng, M. and Mosallam, A. (2007), "Stress strain model for concrete confined by FRP composites", Compos. Part B : Eng., 38(5-6), 614-628.

Zhao, X., Grzebieta, R. and Elchalakani, M. (2002), "Tests of concrete-filled double skin CHS composite stub columns", Steel Compos. Struct., Int. J., 2(2), 129-146. 